This item was submitted to Loughborough's Research Repository by the author.

Items in Figshare are protected by copyright, with all rights reserved, unless otherwise indicated.

\title{
Sulfonated poly(2,5-benzimidazole) (ABPBI)/ MMT/ ionic liquids composite membranes for high temperature PEM applications
}

\section{PLEASE CITE THE PUBLISHED VERSION}

http://dx.doi.org/10.1016/j.ijhydene.2015.07.127

\section{PUBLISHER}

(C) Elsevier B.V.

\section{VERSION}

AM (Accepted Manuscript)

\section{PUBLISHER STATEMENT}

This work is made available according to the conditions of the Creative Commons Attribution-NonCommercialNoDerivatives 4.0 International (CC BY-NC-ND 4.0) licence. Full details of this licence are available at: https://creativecommons.org/licenses/by-nc-nd/4.0/

\section{LICENCE}

CC BY-NC-ND 4.0

\section{REPOSITORY RECORD}

Bao, Xujin, Fan Zhang, and Qingting Liu. 2016. "Sulfonated Poly(2,5-benzimidazole) (ABPBI)/ MMT/ lonic Liquids Composite Membranes for High Temperature PEM Applications". figshare. https://hdl.handle.net/2134/20730. 
Elsevier Editorial System(tm) for International Journal of Hydrogen Energy Manuscript Draft

Manuscript Number: HE-D-15-00919R1

Title: Sulfonated Poly(2,5-benzimidazole) (ABPBI)/ MMT/ Ionic Liquids Composite Membranes for High Temperature PEM Applications

Article Type: SI: The CARISMA conference (Pollet)

Section/Category: Fuel Cells \& Applications

Keywords: Composite materials; ionic liquids; mechanical properties; high temperature PEMFC

Corresponding Author: Dr. Xujin Bao, Ph.D

Corresponding Author's Institution: Loughborough University

First Author: Fan Zhang, PhD

Order of Authors: Fan Zhang, PhD; Xujin Bao, Ph.D; Qingting Liu, PhD

Abstract: The effect of nanoclay cloisite $\mathrm{Na}+$ on the mechanical and conductive properties of ionic liquids (ILs) doped sulfonated ABPBI (SABPBI) composite membranes for high temperature proton electrolyte membrane (PEM) applications were investigated in this report. The composite SABPBI membranes with well-dispersed cloisite $\mathrm{Na}+$ showed great improvement in mechanical properties with the increase of over $90 \%$ in ultimate tensile strength and $40 \%$ in Young's modulus, respectively, compared with those of pristine ABPBI membrane. The ILs absorption was also incraesed due to the incorporation of well-dispersed cloisite $\mathrm{Na}+$, resulting in significant increase in the ionic conductivities of SABPBI membranes at the temperatures above $100^{\circ} \mathrm{C}$. The highest conductivities were $4.0 \times 10-2$ $\mathrm{S} / \mathrm{cm}$ at $220^{\circ} \mathrm{C}$ for [HMIM] Cl doped $3 \mathrm{wt} \% \mathrm{SABPBI}$ composite membranes (doping level 1.32), and $9.6 \times 10-3 \mathrm{~S} / \mathrm{cm} \times 10-3 \mathrm{~S} / \mathrm{cm}$ at $220^{\circ} \mathrm{C}$ for [TMG] [BF4] doped SABPBI composite membranes (doping level 1.37), respectively. 
Suggested reviewers:

\section{Professor Keith Scott}

Department of Chem Eng and Adv Materials

Newcastle University

Newcastle upon Tyne, UK

Keith Scott keith.scott@newcastle.ac.uk

Professor Qingfeng Li

Section of Proton Conductors

Department of Energy Conversion and Storage Kemitorvet B207, Room 064 Technical University of Denmark

DK-2800 Lyngby, Denmark

Qingfeng Li gfli@dtu.dk 
Graphical Abstract

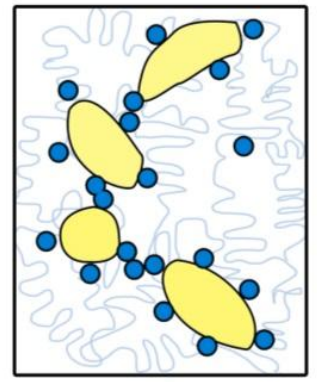

(a)

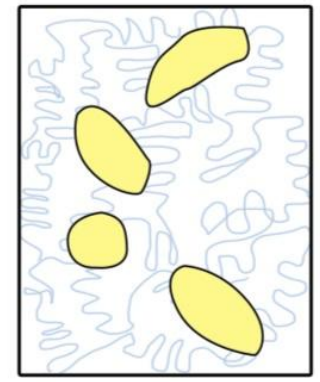

(b)

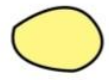

Ionic channel

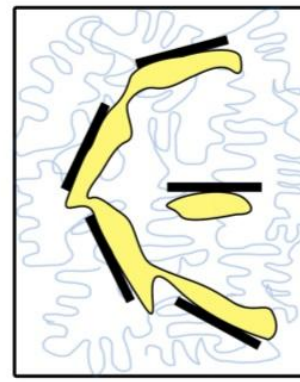

(c)

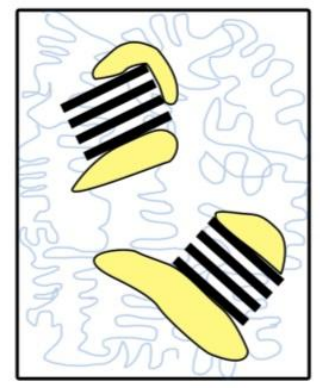

(d)
O

Water
Clay

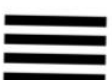

Polymer 
Figure 1

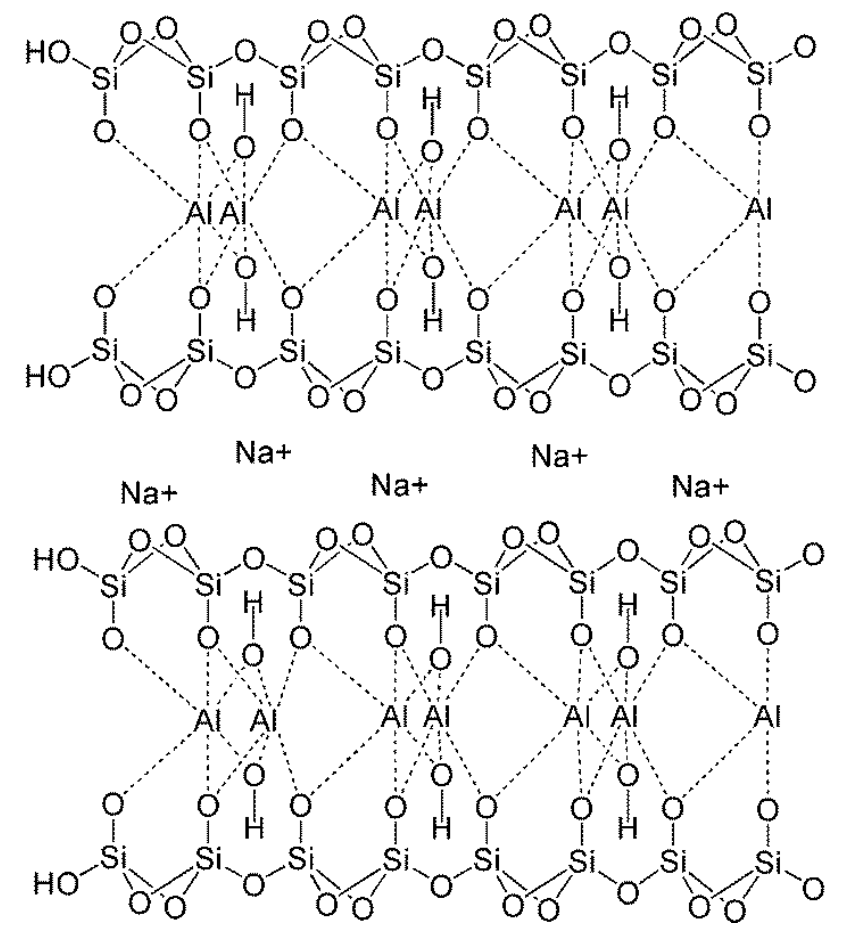


Figure 2

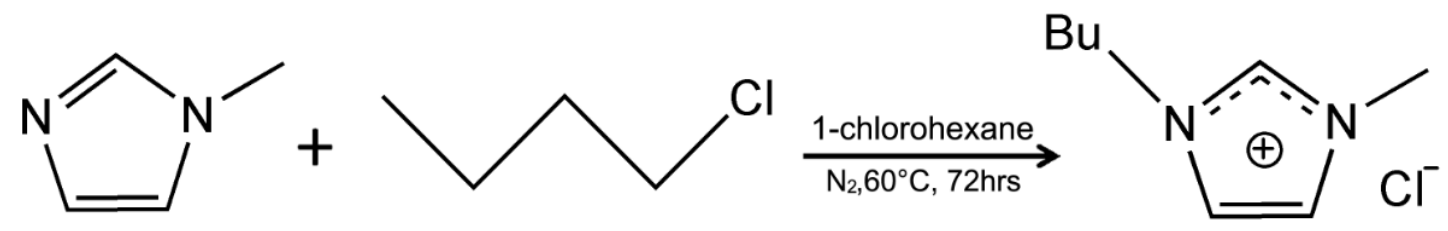


Figure 3<smiles>CN(C)C(=N)N(C)[CH-]CP(C)N(C)C(=[NH2+])N(C)C</smiles> 
Figure 4

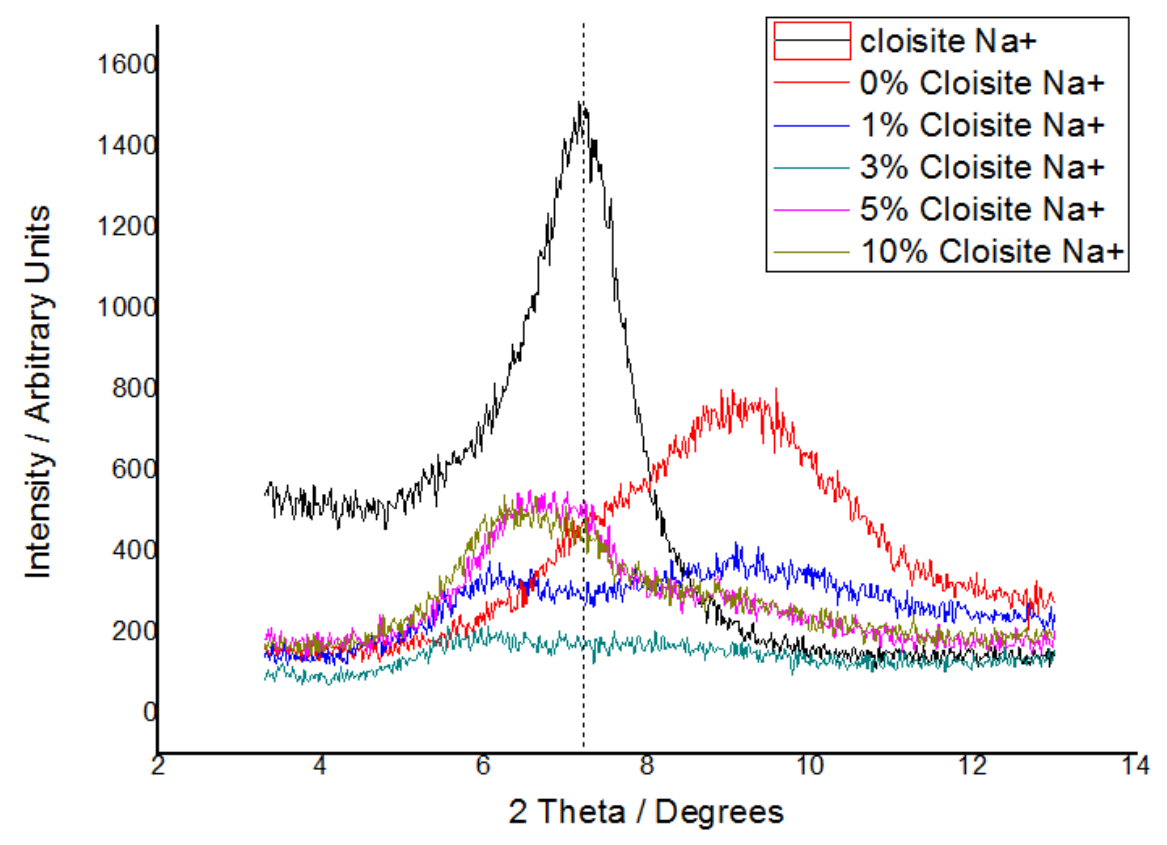




\section{Tables}

Table 1 Activation energy of conductivities of [HMIM]Cl doped ABPBI membranes with various cloisite $\mathrm{Na}^{+}$contents

\begin{tabular}{lcc}
\hline \multicolumn{1}{c}{ Membrane } & $\begin{array}{c}\text { Activation energy }\left(\mathrm{E}_{\mathrm{a}}\right) \\
(\mathrm{kJ} / \mathrm{mol})\end{array}$ & $\begin{array}{c}\text { Temperature range }(\mathrm{T}) \\
\left({ }^{\circ} \mathrm{C}\right)\end{array}$ \\
\hline 0wt\% ABPBI - 0.91 [HMIM]Cl & 53.4 & $50 \sim 220$ \\
$1 \mathrm{wt} \% \mathrm{ABPBI}-0.80[\mathrm{HMIM}] \mathrm{Cl}$ & 33.5 & $50 \sim 220$ \\
3wt\% ABPBI - 1.32 [HMIM]Cl & 31.9 & $50 \sim 220$ \\
$5 \mathrm{wt} \%$ ABPBI - $1.07[\mathrm{HMIM}] \mathrm{Cl}$ & 35.3 & $50 \sim 220$ \\
10wt\% ABPBI - $0.70[\mathrm{HMIM}] \mathrm{Cl}$ & 50.5 & $50 \sim 220$ \\
\hline
\end{tabular}




\section{Table 2}

Table 2 Activation energy of conductivities of [TMG][BF 4 doped ABPBI membranes with various cloisite $\mathrm{Na}^{+}$contents

\begin{tabular}{|c|c|c|}
\hline Membrane & $\begin{array}{l}\text { Activation energy }\left(\mathrm{E}_{\mathrm{a}}\right) \\
(\mathrm{kJ} / \mathrm{mol})\end{array}$ & $\begin{array}{c}\text { Temperature range }(\mathrm{T}) \\
\left({ }^{\circ} \mathrm{C}\right)\end{array}$ \\
\hline $0 \mathrm{wt} \%$ ABPBI - $0.56[\mathrm{TMG}]\left[\mathrm{BF}_{4}\right]$ & 48.5 & $170 \sim 220$ \\
\hline $1 \mathrm{wt} \%$ ABPBI - $0.79[\mathrm{TMG}]\left[\mathrm{BF}_{4}\right]$ & 24.5 & $90 \sim 220$ \\
\hline $3 \mathrm{wt} \%$ ABPBI - $1.37[\mathrm{TMG}]\left[\mathrm{BF}_{4}\right]$ & 26.3 & $90 \sim 220$ \\
\hline $5 \mathrm{wt} \%$ ABPBI - $0.58[\mathrm{TMG}]\left[\mathrm{BF}_{4}\right]$ & 27.9 & $90 \sim 220$ \\
\hline $10 \mathrm{wt} \%$ ABPBI - $0.40[\mathrm{TMG}]\left[\mathrm{BF}_{4}\right]$ & 39.3 & $90 \sim 220$ \\
\hline
\end{tabular}


$20^{\text {th }}$ July 2015

Dear Editors:

\section{Paper title:}

Sulfonated Poly(2,5-benzimidazole) (ABPBI)/ MMT/ Ionic Liquids Composite

Membranes for High Temperature PEM Applications (Ref: HE-D-15-00919)

Response to the reviewers:

Thank you for the comments of the reviewers. The details of the corrections based on the reviewers' comments are as follows:

Reviewer \#1: The article is considered as worthwhile for publication. There is only one minur suggestion regarding Fig. 8 and 10 . Although providing no additional information, a ${ }^{\circ} \mathrm{C}$ scale (or at least some lines representing relvant $\mathrm{C}$ temperatures should be added.

Both Figure 8 and 10 have been corrected and a ${ }^{\circ} \mathrm{C}$ scale has been added. (Due to the addition of Figure 5 (Fig. 5 EDX mappings of Si in composite membranes with (a) $1 \mathrm{wt} \%$, (b) $3 \mathrm{wt} \%$, (c) $5 \mathrm{wt} \%$ and (d) $10 \mathrm{wt} \%$ Cloisite $\mathrm{Na}$ ), Figure 8 and 10 are changed to Figure 9 and 11, respectively in revised version.

Reviewer \#2: This work and paper is interesting. A few comments:

1. The introduction needs to be expanded 2. The figures need to be clearer 3 . The English needs to be improved

1. The introduction has been modified, 7 new references were added, among them five of them cited from International J Hydrogen Energy (ref $6,7,10,14,18$ )

2. A new Figure was added (Fig. 5) and Figure 8 and 10 have been corrected and enlarged, which can be seen much clearer.

3. The manuscript has been thoroughly corrected from the Abstract to Conclusions including re-phase the sentences, correct the English grammar and spelling errors.

Best Regards,

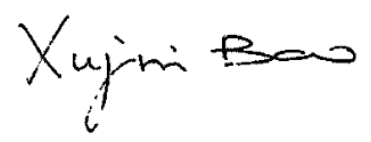

Dr Xujin Bao

Senior Lecturer in Materials, Department of Materials, Loughborough University, Loughborough, Leicestershire LE11 3TU, UK Tel: 0044

(0)1509223150; Email: x.bao@lboro.ac.uk 


\title{
Sulfonated Poly(2,5-benzimidazole) (ABPBI)/ MMT/ Ionic Liquids \\ Composite Membranes for High Temperature PEM Applications
}

\author{
Xujin Bao*, Fan Zhang and Qingting Liu \\ Department of Materials, Loughborough University, LE113TU, UK, 0044(0)1509223150, X.Bao@lboro.ac.uk
}

\begin{abstract}
The effect of nanoclay cloisite $\mathrm{Na}^{+}$on the mechanical and conductive properties of ionic liquids (ILs) doped sulfonated ABPBI (SABPBI) composite membranes for high temperature proton electrolyte membrane (PEM) applications were investigated in this report. The composite SABPBI membranes with well-dispersed cloisite $\mathrm{Na}^{+}$ showed great improvement in mechanical properties with the increase of over $90 \%$ in ultimate tensile strength and $40 \%$ in Young's modulus, respectively, compared with those of pristine ABPBI membrane. The ILs absorption was also incraesed due to the incorporation of well-dispersed cloisite $\mathrm{Na}^{+}$, resulting in significant increase in the ionic conductivities of SABPBI membranes at the temperatures above $100^{\circ} \mathrm{C}$. The highest conductivities were $4.0 \times 10^{-2} \mathrm{~S} / \mathrm{cm}$ at $220^{\circ} \mathrm{C}$ for [HMIM] Cl doped $3 \mathrm{wt} \%$ SABPBI composite membranes (doping level 1.32), and $9.6 \times 10^{-3} \mathrm{~S} / \mathrm{cm} \times 10^{-3} \mathrm{~S} / \mathrm{cm}$ at $220^{\circ} \mathrm{C}$ for $\left[\mathrm{TMG}^{2}\left[\mathrm{BF}_{4}\right]\right.$ doped SABPBI composite membranes (doping level 1.37), respectively.
\end{abstract}

Keywords: Composite materials; ionic liquids; mechanical properties; high temperature PEMFC

\section{Introduction}

Fuel cells are devices that convert chemical energy directly into electric energy with low emission or even zero emission [1]. Proton exchange membrane (PEM) is one of the most important parts for a proton exchange membrane fuel cell, as it largely determines the functionality of the entire fuel cell [2]. Currently, various PEM 
systems that can operate at high temperatures (above $120^{\circ} \mathrm{C}$ ) are being developed [3], as a higher operation temperature of PEM provides improved CO (impurity) tolerance of the electrodes, simplified water management system, enhanced electrochemical kinetics and effective thermal management [4].

Poly(2,5-benzimidazole) (ABPBI) is a useful polymer from Polybenzimidazole (PBI) family, which has high thermal stability, good mechanical properties and low methanol crossover [5]. Ionic liquids (ILs) are salts that exist in liquid state at room temperature, which are composed of bulky, asymmetric organic cations and anions [5]. Their excellent thermal stability and high ionic conductivity make them very suitable to be used in high temperature PEM applications [6][7][8][9][10]. By now, several PBI/ILs systems have been prepared and showed good ionic conductivities[5][11][12][13]. However, for all of these systems, ILs were incorporated into the polymer matrix by mixing ILs with the polymer solutions before casting into membranes, or by being absorbed by porous PBI matrix [14]. The researches on mixing ILs with fabricated dense PBI, which allows the fine turing of individual properties of both conducting medium and polymer matrix, are rare.

In our previous research, a new method to incorporate ILs into ABPBI polymer membrane was developed [15], in which a sulfonated ABPBI membrane was synthesised to improve the compatibility with ILs. Two ILs, 1-Hexyl-3-methylimidazolium chloride $\quad$ ([HMIM]Cl) and 1,1,3,3-Tetramethylguanidine tetrafluoroborate ([TMG][BF4]), were used as the conducting medium. It was found that the sulfonation process greatly improved the IL doping levels as well as their corresponding ionic conductivities, making this sulfonated ABPBI/ILs membrane system to be a promising candidate for high temperature PEMs applications [15]. 


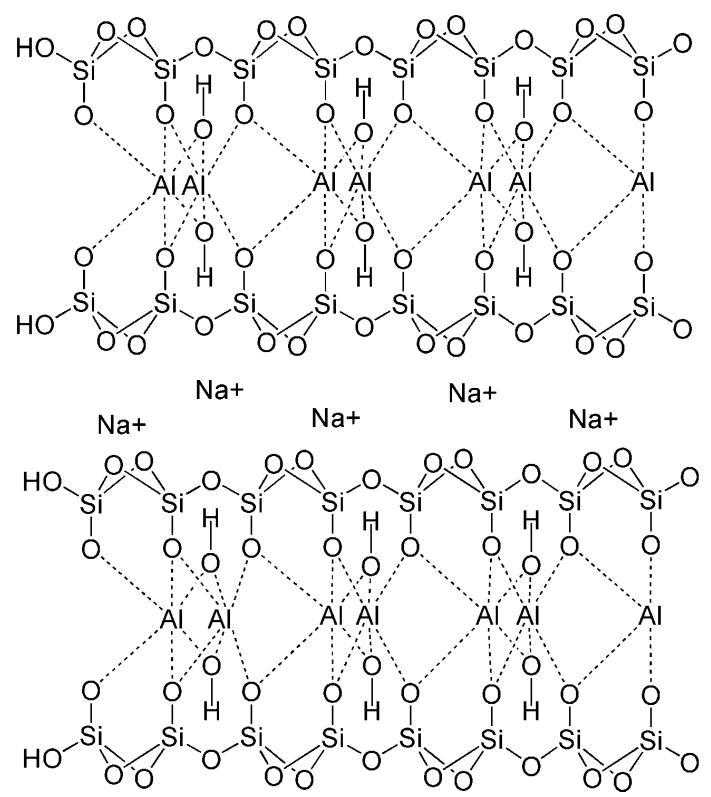

Fig. 1 Structure of MMT nanoclay (Cloisite $\mathrm{Na}^{+}$)

Cloisite $\mathrm{Na}^{+}$, which is a Montmorillonite (MMT) sodium nanoclay (Fig. 1), was used as a nano filler to reinforce ABPBI membrane, due to its high aspect ratio and low price [16][17]. It was reported that sulfonated MMT was used to balance the ionic conductivity and mechanical properties of the composite membranes[18,19]. In this paper, MMT incorporated sulfoanted ABPBI composite membranes are prepared and the effects of the cloisite $\mathrm{Na}^{+}$nanoclay on the mechanical properties, ILs doping levels and ionic conductivities are investigated. The mechanism of the ionic conductivity of the new composite membrane is also discussed.

\section{Materials And Methods}

\subsection{Materials}

\subsubsection{Chemicals}

3,4-Diaminobenzoic acid (DABA), phosphorus pentoxide $\left(\mathrm{P}_{2} \mathrm{O}_{5}\right)$, sulfuric acid, 1-methylimidazole, 1-chlorohexane, cyclohexane, 1,1,3,3-Tetramethylguanidine, fluoroboric acid and ethyl acetate were purchased from Sigma-Aldrich Co, UK. Methanesulfonic acid (MSA) was purchased from Fisher Scientific, UK. All 
chemicals were used directly for the synthesis without further purification.

\subsubsection{Membrane casting}

ABPBI was synthesised using the method reported by Kim et al [2]. The viscous ABPBI/MSA solution was casted onto a glass plate with a doctor blade [20]. The solution was then quickly washed by plenty of deionized water. After about 1 minute, a piece of translucent membrane was obtained. The thickness of the resulted membrane was controlled by adjusting the gap between the blade and the plate, as well as the concentration of the ABPBI/MSA solution.

\subsubsection{Sulfonation of ABPBI membranes}

As reported by Asensio et al [21], ABPBI membranes were soaked in 98wt\% $\mathrm{H}_{2} \mathrm{SO}_{4} / \mathrm{H}_{2} \mathrm{O}$ solution (10:90 by volume) for 24 hours, dried at $100^{\circ} \mathrm{C}$ and heat treated using a furnace at $450^{\circ} \mathrm{C}$ for 5 minutes. They were then washed in deionized water for 2 hours and dried again.

\subsubsection{Synthesis of $[\mathrm{HMIM}] \mathrm{Cl}$}

For the preparation of 1-Hexyl-3-methylimidazolium chloride ([HMIM]Cl) (Fig. 2), 1-Methylimidazole $(16.4 \mathrm{~g}, 0.2 \mathrm{~mol})$ and $50 \mathrm{~mL}$ anhydrous cyclohexane were added into a $250 \mathrm{~mL}$ three-neck round bottom flask with a reflux condenser. After applied with nitrogen gas and cooled in an ice-bath, 1-chlorohexane $(29.5 \mathrm{~g}, 0.24 \mathrm{~mol})$ was added dropwise into the vigorously stirred mixture. After refluxing at $60^{\circ} \mathrm{C}$ for 72 hours, the hot mixture was poured into a separating funnel. A viscous, light-yellow-color product was obtained. The product was then washed twice with ethyl acetate, and the solvent was removed using a rotary evaporator at $70^{\circ} \mathrm{C}$. After dried in a vacuum oven at $70^{\circ} \mathrm{C}$ for 24 hours, pure [HMIM]Cl was obtained, with a yield of 55.4\%. 


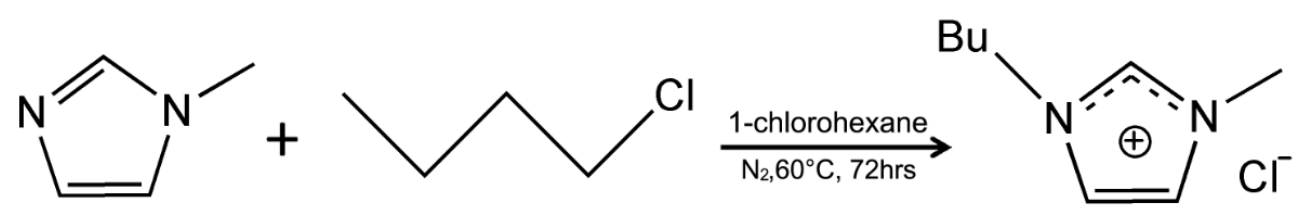

Fig. 2 Synthesis of [HMIM]Cl

\subsubsection{Synthesis of $\left[\mathrm{TMG}^{\mathrm{N}}\right]\left[\mathrm{BF}_{4}\right]$}

1,1,3,3-Tetramethylguanidine tetrafluoroborate $\left([\mathrm{TMG}]\left[\mathrm{BF}_{4}\right]\right)$ was synthesised by mixing 1,1,3,3-Tetramethylguanidine $(23.0 \mathrm{~g}, 0.2 \mathrm{~mol})$ and fluoroboric acid (17.6g, $0.2 \mathrm{~mol}$ ) in a $100 \mathrm{~mL}$ flask placed in an ice bath for 24 hours (Fig. 3). The un-reacted componds and solvent were removed using a rotary evaporator at $70^{\circ} \mathrm{C}$. After dired in

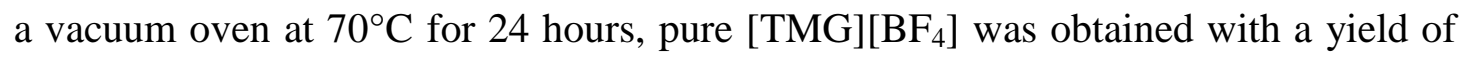
$72.8 \%$.

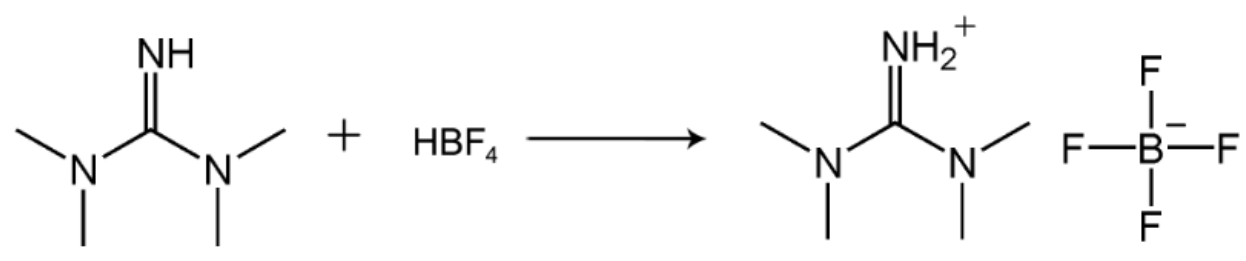

Fig. 3 Synthesis of [TMG][BF 4$]$

\subsection{Characterisations}

An X-ray diffraction measurement device (D2 Phaser, Bruker) was used to charaterise the dispersion of nanoclay in the ABPBI matrix. The wavelength of the incident ray was $1.54 \AA$, and the scanning range $2 \theta$ was from $1^{\circ}$ to $25^{\circ}$. The mechanical properties of the ABPBI and ABPBI/MMT composite membranes were measured using a universal tensile test machine (Model Lr50K, Lloyd Instrument, UK). The samples were prepared according to ASTM D638 (gauge length $10 \mathrm{~mm}$, width $2.5 \mathrm{~mm}$, crosshead speed $50 \mathrm{~mm} / \mathrm{min}$ and load cell $1.0 \mathrm{kN}$ ). A field emission gun scanning electron microscope (FEGSEM), (Carl Zeiss, 1530V) was used in conjunction with energy dispersive X-ray (EDX) to perform the membrane surface characterisation and 
elemental analysis.

The ionic liquid doping levels were directly determined by measuring the weights of the membranes before $\left(\mathrm{m}_{1}\right)$ and after $\left(\mathrm{m}_{2}\right)$ doping in the ionic liquid, and was obtained from the relation:

$$
\begin{gathered}
\text { [HMIM]Cl doping level }=\frac{\left(m_{2}-m_{1}\right) / 175}{m_{1} / 116} \\
{\left[\text { TMG] }\left[\mathrm{BF}_{4}\right] \text { doping level }=\frac{\left(m_{2}-m_{1}\right) / 202}{m_{1} / 116}\right.}
\end{gathered}
$$

175, 202 and 116 represent the relative molecular mass of [HMIM]Cl, [TMG] $\left[\mathrm{BF}_{4}\right]$ and the repeat unit of ABPBI, respectively.

The impedance of the membranes was measured using electrochemical impedance spectroscopy (EIS), where a Solartron Analytical 1280 electrochemical measurement unit (1280 EMU, Solartron Analytical Ltd.) was employed. The frequency range was $1 \mathrm{M}$ to $100 \mathrm{~Hz}$ and the $\mathrm{AC}$ amplitude was $100 \mathrm{mV}$. The samples were sandwiched between two circular platinum $(\mathrm{Pt}$ ) electrodes (diameter $2.00 \mathrm{~mm}$, purity $99.95 \%$, Goodfellow Cambridge Ltd.), and were fixed firmly into a PTFE cell with two springs. A piece of pressure indicating film (Pressure ${ }^{\circledR}$ ) was used to measure the compression pressure applied on the membrane, which was between 350 psi and 1400 psi. The cell was then placed into a tube furnace to conduct the impedance measurement at elevated temperatures. The proton conductivity $(\sigma)$ of an electrochemical cell can be calculated by the equation

$$
\sigma=d /(R \times A)
$$

where $\mathrm{d}$ is the distance between two electrodes, i.e. the membrane thickness in this case, $\mathrm{cm}$; $\mathrm{R}$ is the bulk resistance of the sample with the unit $\Omega$; A is the contact area, $\mathrm{cm}^{2}$. 


\section{Results And Discussions}

\subsection{Dispersion of cloisite $\mathrm{Na}^{+}$in $\mathrm{ABPBI}$ polymer matrix}

Figure 4 shows the $\mathrm{x}$-ray diffraction spectra of cloisite $\mathrm{Na}^{+}$powder, pristine ABPBI and their composite membranes. A sharp peak at $7.16^{\circ}$ was found in the spectrum of cloisite $\mathrm{Na}^{+}$powder, which suggested the presence of layered structure with a d-spacing calculated to be $1.23 \mathrm{~nm}$. The broad peak at around $9.23^{\circ}$ was resulted from the amorphous ABPBI structure.

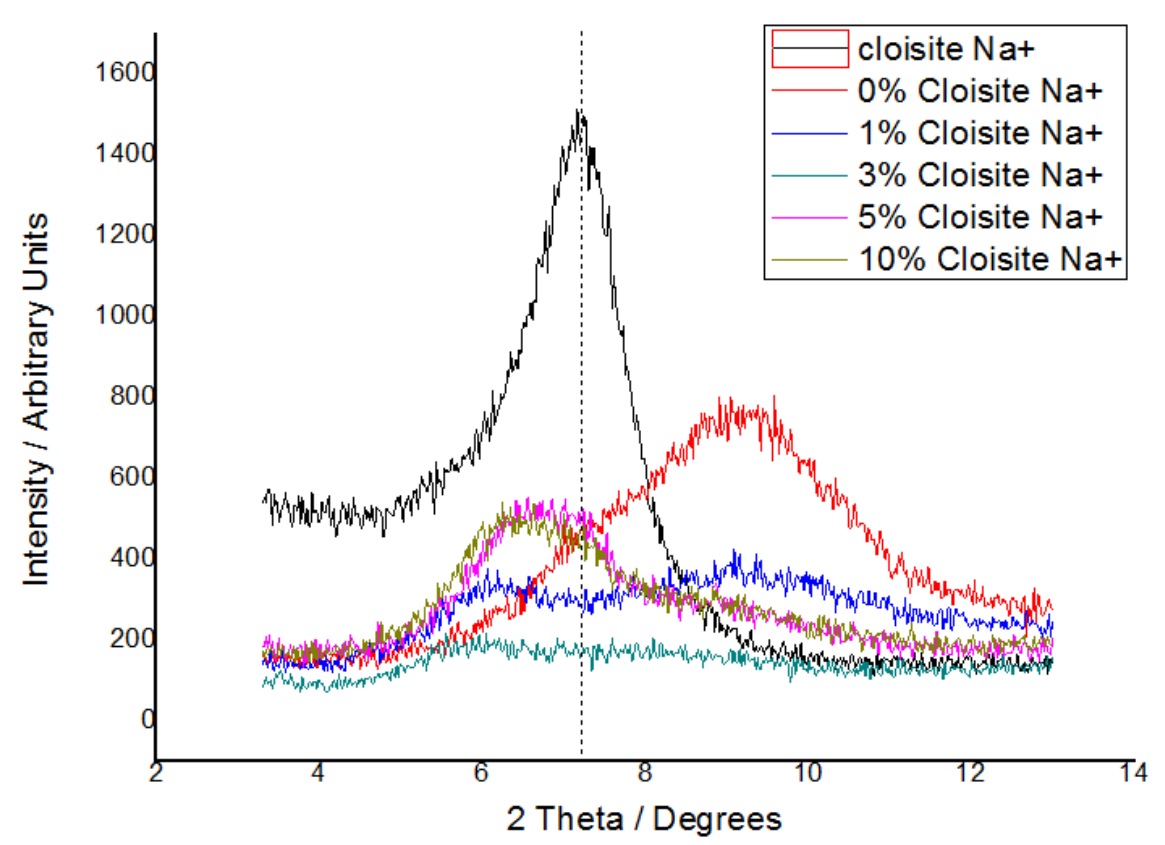

Fig. 4 the XRD spectra of cloisite $\mathrm{Na}^{+}$powder, and $\mathrm{ABPBI} /$ Cloisite $\mathrm{Na}^{+}$composite membranes

In the spectrum of $1 \mathrm{wt} \%$ cloisite $\mathrm{Na}^{+}$incorporated ABPBI membrane, a small peak at $5.94^{\circ}$ indicates the presence of cloisite $\mathrm{Na}^{+}$in the composite membrane. Compared to the cloisite $\mathrm{Na}^{+}$powder, this peak in $1 \mathrm{wt} \%$ membrane shifts to the lower diffraction angles, suggesting that the distance between layers is expanded as polymer chains are intercalated into the structure. The d-spacing of this intercalated nanoclay increased to $1.49 \mathrm{~nm}$.

No obvious peak was found in the spectrum of $3 \mathrm{wt} \%$ cloisite $\mathrm{Na}^{+}$incorporated 
ABPBI membrane, indicating a good dispersion and exfoliation of clays in the polymer matrix was achieved. The ABPBI crystalline peak also disappeared due to the hindrance effect of nanoclay on the formation of crystalline structure of the polymer.

The spectra of $5 \mathrm{wt} \%$ and $10 \mathrm{wt} \%$ membranes looked quite identical. Compared to cloisite $\mathrm{Na}^{+}$powder, the composite membranes showed a major peak at lower angle around $6.65^{\circ}$ and an overlapped small peak at the same angle of nanoclay. The corresponding $\mathrm{d}$-spacing for the lower angle is $1.33 \mathrm{~nm}$, which is attributed to the intercalation of the clays. The small peak at $7.16^{\circ}$ indicates that agglomerates form in the $5 \mathrm{wt} \%$ and $10 \mathrm{wt} \%$ membranes.

Fig. 5 shows the EDX map of Silicon in the composite membranes, which is a characteristic element in Cloisite $\mathrm{Na}^{+}$and can be used to characterise the dispersion and distribution of the nanoclays in polymer matrix. An uniform distribution and dispersion of $\mathrm{Si}$ element in the membranes with (a) $1 \mathrm{wt} \%$ and (b) $3 \mathrm{wt} \%$ nanoclay content, indicating good dispersions of nanoclay in the polymer matrix. An obvious agglomeration of nanoclays can be observed in (c) $5 \%$ and (d) $10 \%$ membranes. These EDX mappings are supporting the XRD results, which indicate that ABPBI membrane with $3 \%$ Cloisite $\mathrm{Na}^{+}$possesses the best degree of exfoliation and good dispersion of nanoclay in the polymer matrix, which is critical for the improvements of the properties of composite membranes.

\subsection{Mechanical properties of the ABPBI and ABPBI/cloisite $\mathrm{Na}^{+}$composite membranes}

The ultimate tensile strength and Young's modulus of ABPBI membranes with various cloisite $\mathrm{Na}^{+}$contents were measured by tensile tests and the results are shown in Figure 6. 


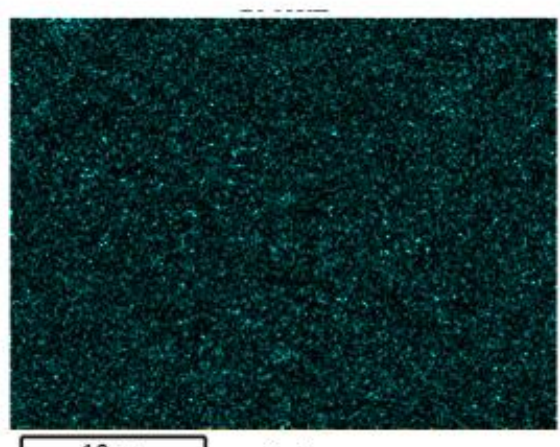

(a)

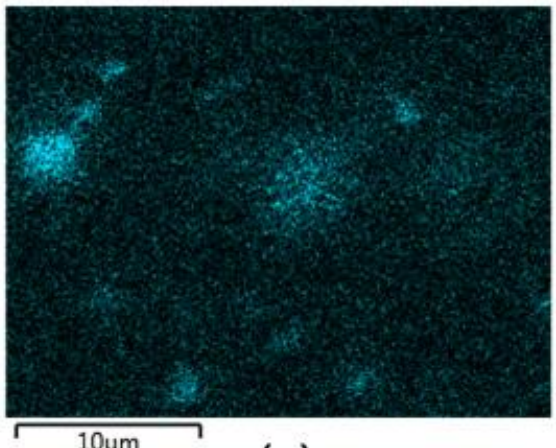

(c)

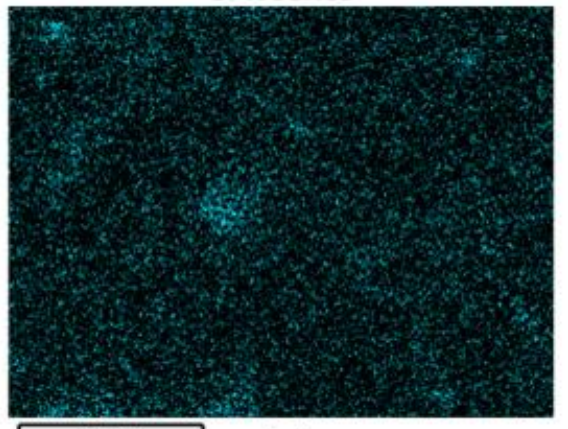

(b)

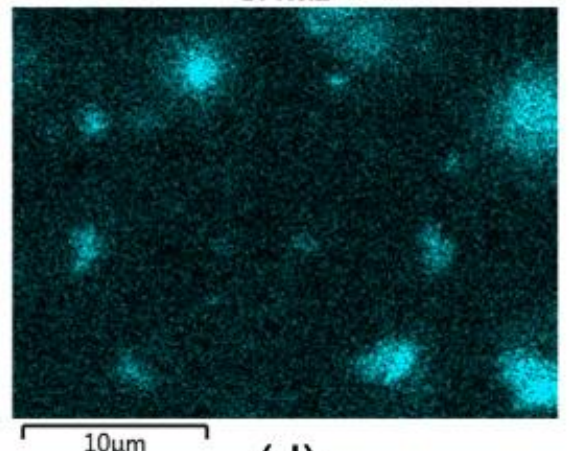

(d)

Fig. 5 EDX mappings of Si in composite membranes with (a) 1 wt\%, (b) 3 wt\%, (c) 5 wt\% and (d) 10 wt \% Cloisite $\mathrm{Na}^{+}$

The ultimate tensile strength (UTS) of pristine ABPBI membrane was $46.4( \pm 16.4)$ MPa. The UTS of the composite membranes was increased with the increase of nanoclay content, and reached the maximum of $88.8( \pm 25.3) \mathrm{MPa}$ at the clay content of $3 w t \%$. A decrease of the UTS was observed when more clays were added, which was mainly due to the aggregation of the nanoclays. The Young's modulus of the composite membranes showed the same tendency as the UTS. The $3 \mathrm{wt} \%$ membrane showed the highest modulus of $1.74( \pm 0.45) \mathrm{GPa}$ compared with $1.30( \pm 0.38) \mathrm{GPa}$ for pure ABPBI membrane. The lowest Young's modulus of $0.95( \pm 0.16) \mathrm{GPa}$ was observed for the $10 \mathrm{wt} \%$ composite membrane. 


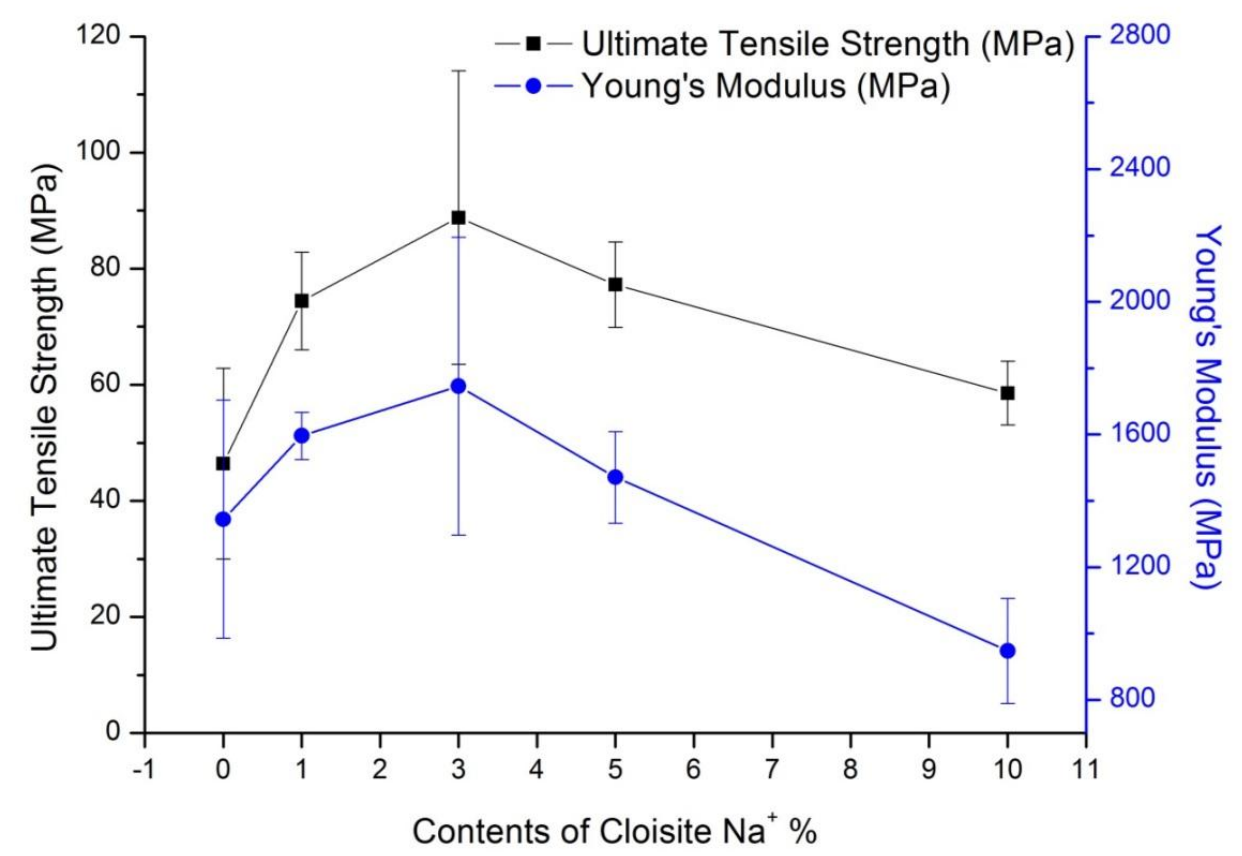

Fig. 6 The ultimate tensile strength and Young's modulus of ABPBI and composite membranes with different cloisite $\mathrm{Na}^{+}$contents

Both the maximum UTS and Young's modulus was achieved by the composite membrane with $3 \mathrm{wt} \%$ nanoclay, which was attributed to the good dispersion of nanoclay in the polymer matrix. XRD results in section 3.1 showed that the best exfoliation was observed in $3 \mathrm{wt} \%$ cloisite $\mathrm{Na}^{+} \mathrm{ABPBI}$ composite membrane and the clays were evenly dispersed in the polymer matrix. The uniformly dispersed nanoclays not only introduce increased volume fraction of nanoclays, which possess much higher strength than the polymer matrix, resulting in enhanced strength and modulus but also the local stress from the matrix can be transferred to rigid exfoliated nanoclay to interrupt and delay the propagation of micro-cracks by stress distribution due to its high aspect ratio, leading to improved tensile strength. Additionally, the hydroxyl groups on cloisite $\mathrm{Na}^{+}$can interact with ABPBI polymer chains to form hydrogen bonding with the secondary amine groups of ABPBI, improving the compatibility between the fillers and matrix, leading to enhanced mechanical properties of the composites. 


\subsection{Effects of nanoclay content on ILs absorption}

The IL doping level of sulfonated ABPBI membranes with different nanoclay contents is presented in Fig 7. It can be seen that as the nanoclay content increases, the IL doping levels increase and reached to the maximum when the nanoclay percentages reaches to $3 \mathrm{wt} \%$, which can be attributted to formations of hydrogen bonds or ionic interactions between the hydroxyl groups on the nanoclay and nitrogen in ionic liquids as shown in Fig 8. A further increase of the clay content results in the decrease of doping levels of the ionic liquids.

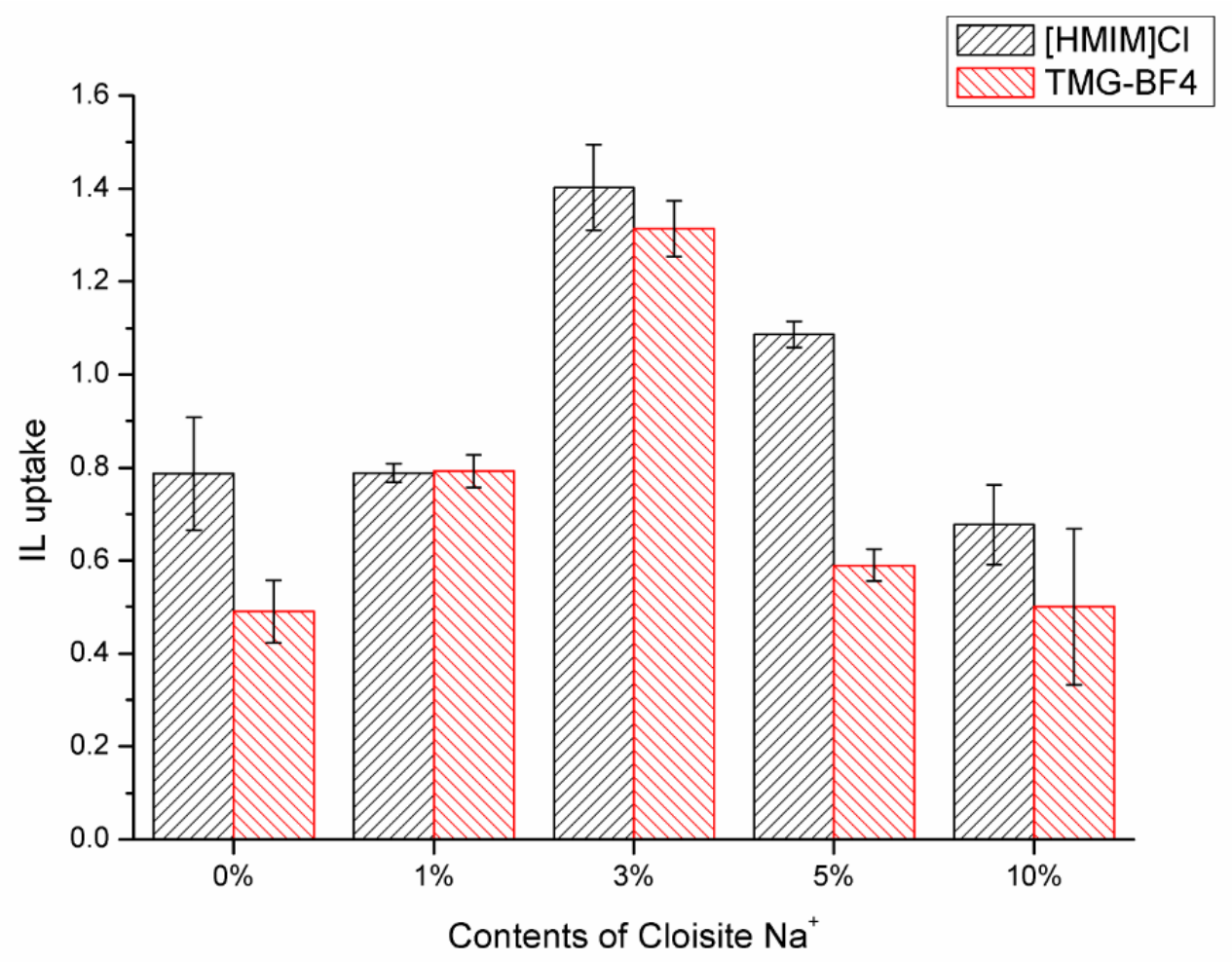

Fig. 7 The ILs doping levels of membranes with different nanoclay content

As shown in Figure 7, the ILs doping level of 0.79 for $1 \mathrm{wt} \%$ cloisite $\mathrm{Na}^{+}$ABPBI membranes is slightly higher than that of pure ABPBI membrane. The due to the interactions between nanoclay and ionic liquids. $3 \mathrm{wt} \%$ cloisite $\mathrm{Na}^{+}$ABPBI membranes possessed the highest ILs doping levels, which were about 1.4 for [HMIM]Cl and 1.3 for $\left[\mathrm{TMG}^{\mathrm{H}}\right]\left[\mathrm{BF}_{4}\right]$, respectively, due to the maximum clay surface areas generated by the good dispersion and exfoliation of nanoclays in the polymer 
matrix. The ILs doping levels of 5wt\% and 10wt $\%$ membranes were obviously lower than those of $3 \mathrm{wt} \%$ membrane, owing to the agglomeration of nanoclay. Agglomerated nanoclay has smaller specific surface area, which reduces the effective clay surfaces for the formation of hydrogen bonds between ionic liquids and nanoclay.

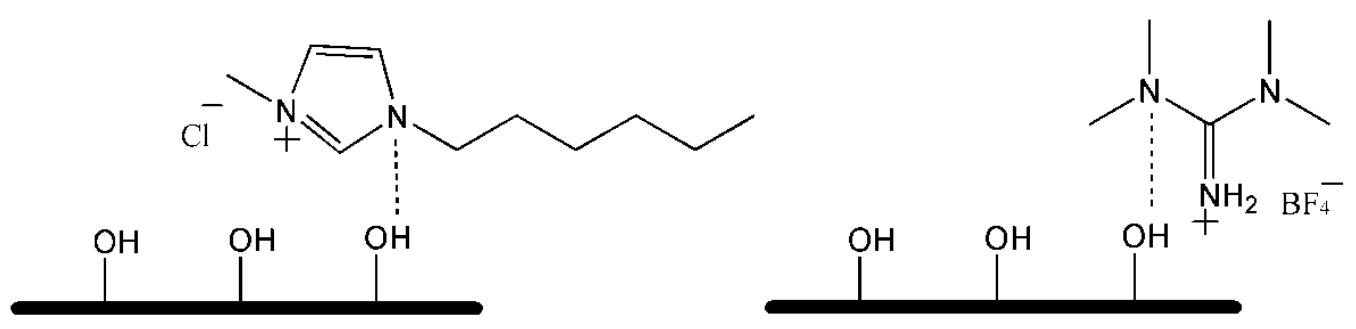

Fig. 8 Interactions between cloisite $\mathrm{Na}^{+}$and ionic liquids

\subsection{Conductivities of anhydrous $\mathrm{SABPBI} /$ cloisite $\mathrm{Na}^{+} /[\mathrm{HMIM}] \mathrm{Cl}$ composite membranes}

The proton conductivities of $[\mathrm{HMIM}] \mathrm{Cl}$ doped $\mathrm{ABPBI} /$ cloisite $\mathrm{Na}^{+}$composite membranes with different nanoclay contents at different temperatures are shown in Fig. 9. Their corresponding activation energy $\left(\mathrm{E}_{\mathrm{a}}\right)$ are tabulated in Table 1.

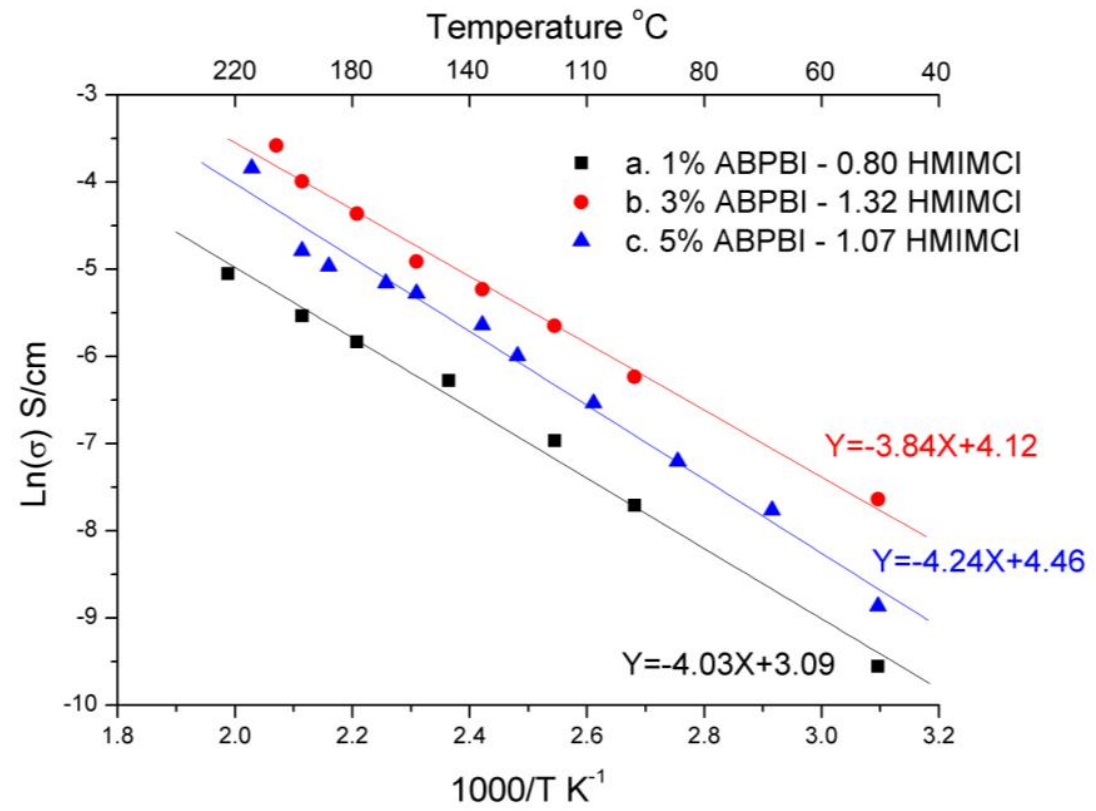




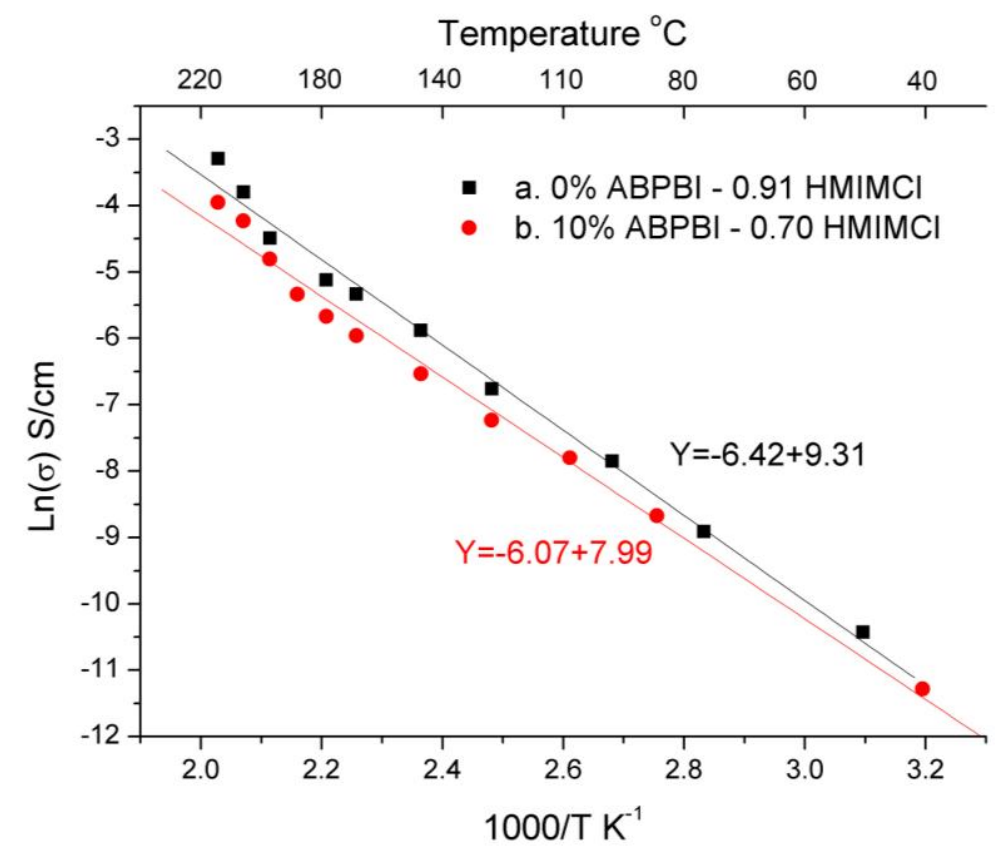

(II)

Fig. 9 The Arrhenius plots of conductivities of [HMIM]Cl doped composite membranes with (I):

(a) $1 \mathrm{wt} \%$, (b) $3 \mathrm{wt} \%$, (c) $5 \mathrm{wt} \%$ cloisite $\mathrm{Na}^{+}$; (II): (d) $0 \mathrm{wt} \%$ and (e) $10 \mathrm{wt} \%$ cloisite $\mathrm{Na}^{+}$.

For sample a, b and c shown in Figure 9, 3wt\% composite membrane with 1.32 [HMIM]Cl doping level showed the highest conductivity, which is $4.0 \times 10^{-2} \mathrm{~S} / \mathrm{cm}$ at $220^{\circ} \mathrm{C}$, while the $1 \mathrm{wt} \%$ sample with 0.80 [HMIM]Cl doping level the lowest, which is $6.4 \times 10^{-3} \mathrm{~S} / \mathrm{cm}$ at $220^{\circ} \mathrm{C}$. As shown in Table 1 , the activation energies $\left(\mathrm{E}_{\mathrm{a}}\right)$ of the compsoite membranes with clay content of $1 \mathrm{wt} \%, 3 \mathrm{wt} \%$ and $5 \mathrm{wt} \%$ are in the range between 30 35 kJ/mol. [HMIM]Cl doped pristine ABPBI membrane and 10wt\% composite membrane showed much higher $\mathrm{E}_{\mathrm{a}}$ values, which are $53.4 \mathrm{~kJ} / \mathrm{mol}$ and $50.5 \mathrm{~kJ} / \mathrm{mol}$, respectively (Figure $9 \mathrm{~d}$ and e), suggesting that the proton transfer mechanisms for these membranes were different. 
Table 1 Activation energy of conductivities of [HMIM]Cl doped composite membranes with various cloisite $\mathrm{Na}^{+}$contents

\begin{tabular}{ccc}
\hline Membrane & $\begin{array}{c}\text { Activation energy }\left(\mathrm{E}_{\mathrm{a}}\right) \\
(\mathrm{kJ} / \mathrm{mol})\end{array}$ & $\begin{array}{c}\text { Temperature range }(\mathrm{T}) \\
\left({ }^{\circ} \mathrm{C}\right)\end{array}$ \\
\hline 0wt\% ABPBI - 0.91 [HMIM]Cl & 53.4 & $50 \sim 220$ \\
$1 \mathrm{wt} \% \mathrm{ABPBI}-0.80[\mathrm{HMIM}] \mathrm{Cl}$ & 33.5 & $50 \sim 220$ \\
3wt\% ABPBI - 1.32 [HMIM]Cl & 31.9 & $50 \sim 220$ \\
$5 \mathrm{wt} \% \mathrm{ABPBI}-1.07[\mathrm{HMIM}] \mathrm{Cl}$ & 35.3 & $50 \sim 220$ \\
$10 \mathrm{wt} \% \mathrm{ABPBI}-0.70[\mathrm{HMIM}] \mathrm{Cl}$ & 50.5 & $50 \sim 220$ \\
\hline
\end{tabular}

As $[\mathrm{HMIM}] \mathrm{Cl}$ is an aprotic ionic liquid, it has no exchangeable $\mathrm{H}$, and its exact proton conduction mechanism is unclear at present. The considerable proton conductivity indicates the formation of a ligand that facilitates proton motion, which may suggest an essential role played by residual water on the sulfonate groups [21]. The last water molecule on the sulfonate group is difficult to remove, even by drying under vacuum [22]. One hypothesis of the proton conducting mechanism is the ionic channel theory [5][12][13], which can be applied to explain this ABPBI/[HMIM]Cl/cloisite $\mathrm{Na}^{+}$system. The ionic liquid in the membrane can interact with the sulfonate groups $\left(-\mathrm{SO}_{3} \mathrm{H}\right)$ on $\mathrm{ABPBI}$ polymer chains and the hydroxyl groups $(-\mathrm{OH})$ on cloisite $\mathrm{Na}^{+}$, which may form hydrophilic channels within the membranes that can enhance the conductivity, as illustrated in Figure 10.

In anhydrous condition, when the ionic liquid doping level is low, the ionic channels may be isolated from each other, resulting in low conductivity and high $E_{a}$ value (Figure 10b). With exfoliated and well distributed nanoclay in the polymer matrix, the ionic liquids which interact with the nanoclay tend to connect to each other, forming continuous ionic channels (Figure 10c), and hence low $\mathrm{E}_{\mathrm{a}}$ values are obtained. When the nanoclay content reaches to high percentage of $10 \mathrm{wt} \%$, the clays tend to form large agglomerates rather than disperse evenly in the matrix, which results in low IL uptake and isolated ionic channels (Figure 10d) and higher Ea values . 


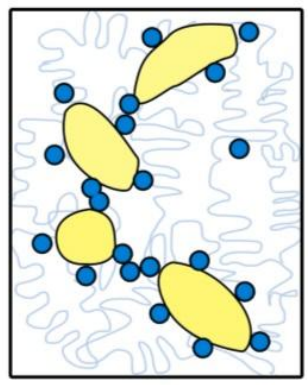

(a)

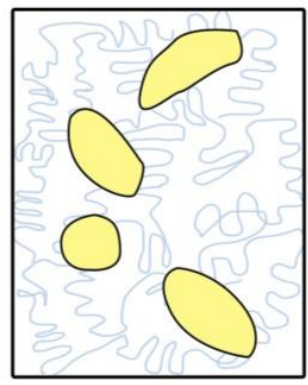

(b)

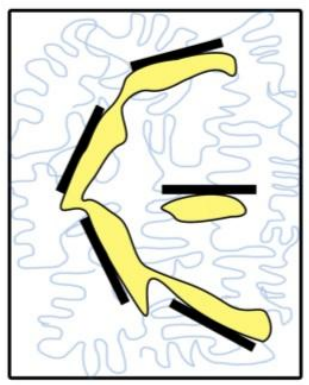

(c)

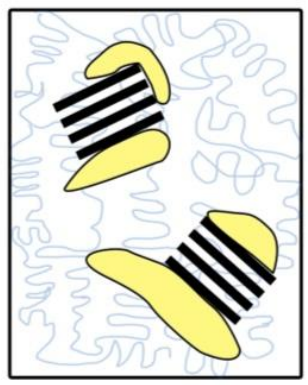

(d)

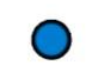

Water

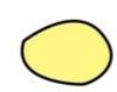

Ionic channel

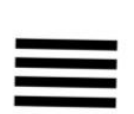

Clay

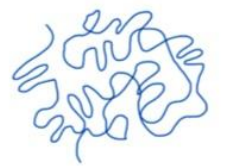

Polymer

Fig. 10 Schematic of ABPBI/[HMIM]Cl/cloisite $\mathrm{Na}^{+}$ionic channel system, (a) hydrous condition, (b) anhydrous condition, (c) exfoliated nanoclay/ILs and (d) agglomeration of nanoclay/ILs

\subsection{Conductivities of anhydrous $\mathrm{SABPBI} /$ cloisite $\mathrm{Na}^{+} /[\mathrm{TMG}]\left[\mathrm{BF}_{4}\right]$ composite membranes}

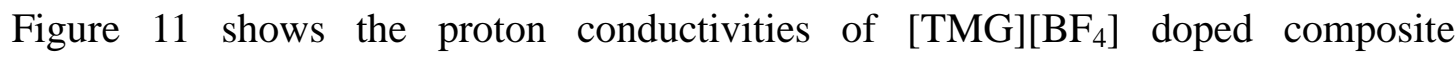
membranes with various cloisite $\mathrm{Na}^{+}$contents at different temperatures. Their corresponding activation energy $\left(\mathrm{E}_{\mathrm{a}}\right)$ values are tabulated in Table 2.

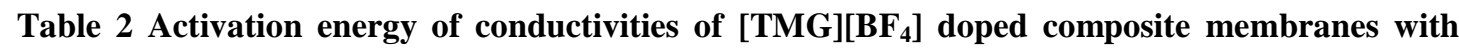
various cloisite $\mathrm{Na}^{+}$contents

\begin{tabular}{|c|c|c|}
\hline Membrane & $\begin{array}{c}\text { Activation energy }\left(\mathrm{E}_{\mathrm{a}}\right) \\
(\mathrm{kJ} / \mathrm{mol})\end{array}$ & $\begin{array}{c}\text { Temperature range }(\mathrm{T}) \\
\left({ }^{\circ} \mathrm{C}\right)\end{array}$ \\
\hline $0 \mathrm{wt} \%$ ABPBI - $0.56[\mathrm{TMG}]\left[\mathrm{BF}_{4}\right]$ & 48.5 & $170 \sim 220$ \\
\hline $1 \mathrm{wt} \%$ ABPBI - $0.79[\mathrm{TMG}]\left[\mathrm{BF}_{4}\right]$ & 24.5 & $90 \sim 220$ \\
\hline $3 \mathrm{wt} \%$ ABPBI - $1.37[\mathrm{TMG}]\left[\mathrm{BF}_{4}\right]$ & 26.3 & $90 \sim 220$ \\
\hline $5 \mathrm{wt} \%$ ABPBI $-0.58[\mathrm{TMG}]\left[\mathrm{BF}_{4}\right]$ & 27.9 & $90 \sim 220$ \\
\hline $10 \mathrm{wt} \%$ ABPBI - $0.40[\mathrm{TMG}]\left[\mathrm{BF}_{4}\right]$ & 39.3 & $90 \sim 220$ \\
\hline
\end{tabular}




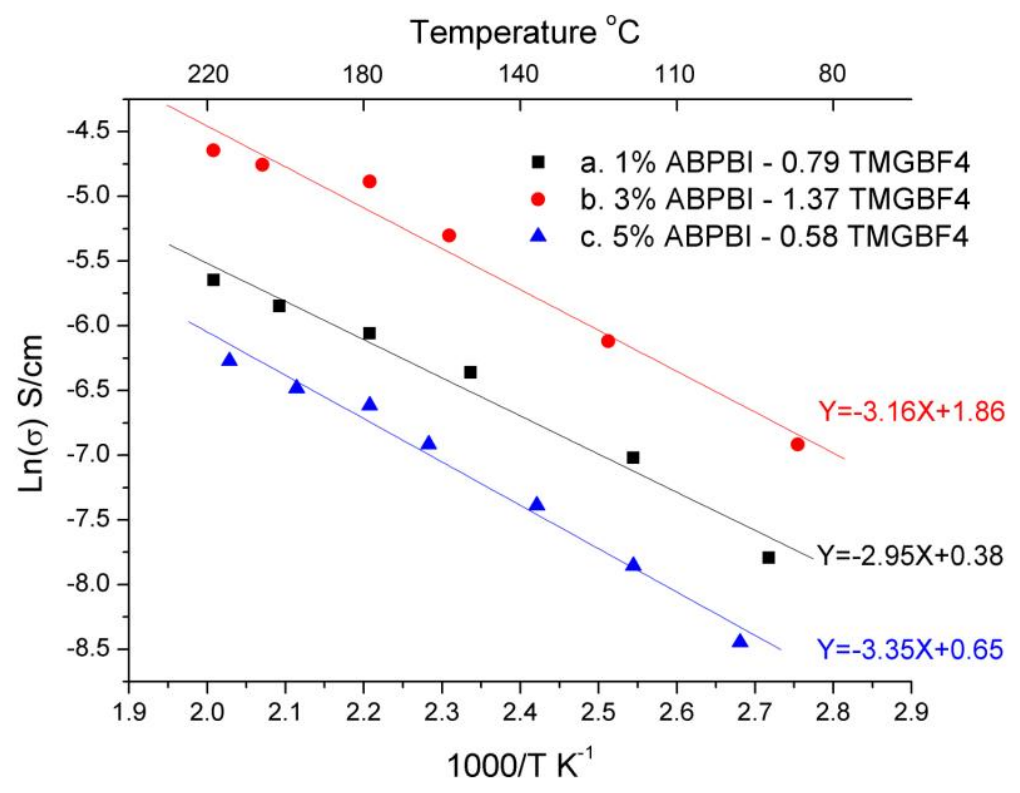

(I)

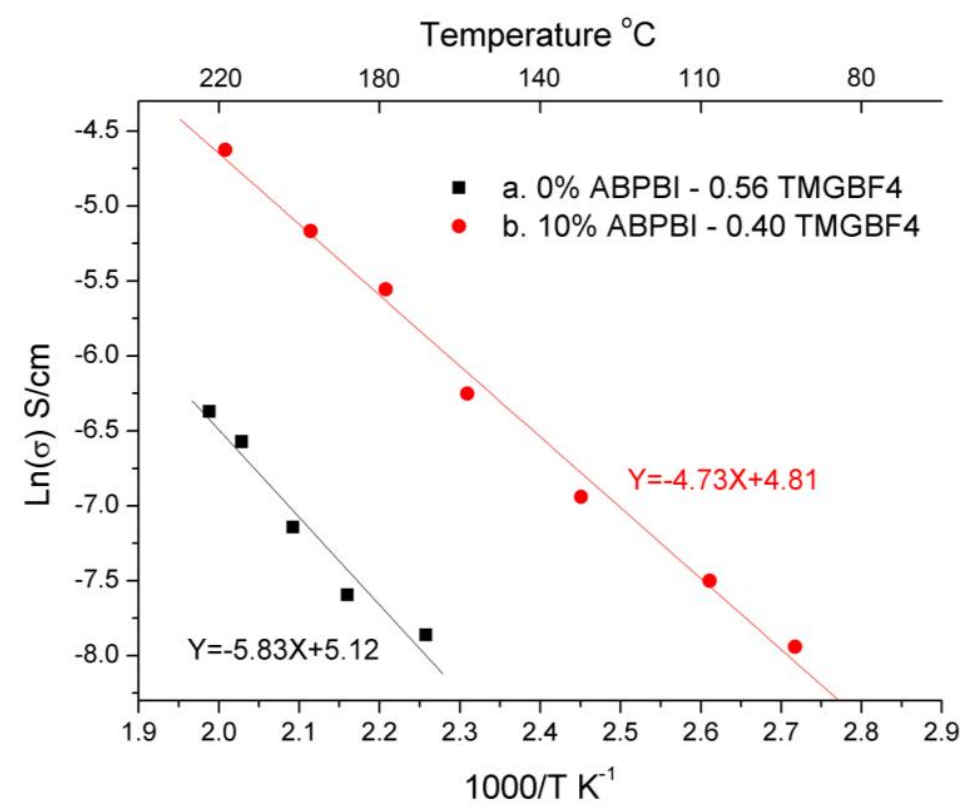

(II)

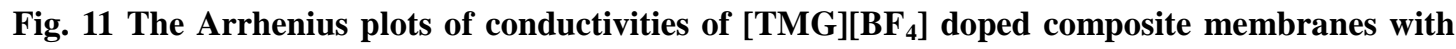
(I): (a) $1 \mathrm{wt} \%$, (b) $3 \mathrm{wt} \%$, (c) $5 \mathrm{wt} \%$ cloisite $\mathrm{Na}^{+}$; (II): (d) $0 \mathrm{wt} \%$ and (e) $10 \mathrm{wt} \%$ cloisite $\mathrm{Na}^{+}$.

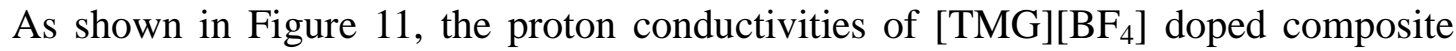
membranes increased with the increase of the $[\mathrm{TMG}]\left[\mathrm{BF}_{4}\right]$ uptake. The $3 \mathrm{wt} \%$ 


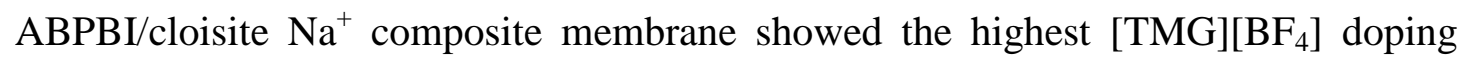
level of 1.37 and the highest proton conductivity of $9.6 \times 10^{-3} \mathrm{~S} / \mathrm{cm}$ at $220^{\circ} \mathrm{C}$, while $5 \mathrm{wt} \%$ membrane (c) showed the lowest doping level of 0.58 and the lowest conductivity of $1.9 \times 10^{-3} \mathrm{~S} / \mathrm{cm}$ at $220^{\circ} \mathrm{C}$. The $\mathrm{E}_{\mathrm{a}}$ values of these three membranes are in the range between $24 \sim 28 \mathrm{~kJ} / \mathrm{mol}$.

Similar to the case in [HMIM]Cl doped composite membranes, [TMG][BF 4 doped ABPBI (d) and 10wt \% cloisite $\mathrm{Na}^{+}$incorporated ABPBI membranes (e) also showed much higher $E_{\mathrm{a}}$ values, which were $48.5 \mathrm{~kJ} / \mathrm{mol}$ and $39.3 \mathrm{~kJ} / \mathrm{mol}$, respectively. It is noteworthy that $\mathrm{E}_{\mathrm{a}}$ of $[\mathrm{TMG}]\left[\mathrm{BF}_{4}\right]$ doped $0 \mathrm{wt} \%$ ABPBI membrane was calculated from the temperatures above $170^{\circ} \mathrm{C}$ due to the conductivity stagnation at $100 \sim 160^{\circ} \mathrm{C}$ in which the Arrhenius plot was not linear against the increased temperature.

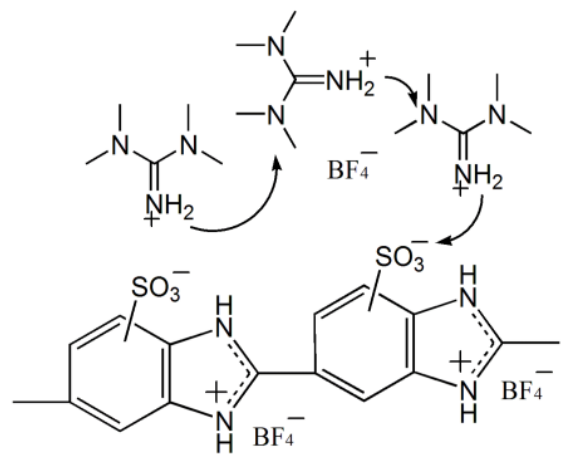

Fig. 12 Proton transfer between [TMG][BF $]$ molecules and sulfonate groups

The similarity of the results with those of [HMIM]Cl doped composite membranes may imply that the ionic channel theory can also be applied to explain the proton conduction mechanism of $[\mathrm{TMG}]\left[\mathrm{BF}_{4}\right]$ doped ABPBI membranes. As illustrated in Figure $12,[\mathrm{TMG}]\left[\mathrm{BF}_{4}\right]$ is a protic ionic liquid, which possesses an exchangeable $\mathrm{H}$, allowing proton to jump between ionic liquid molecules. As discussed in previous section, well-developed ionic channels tend to form within the ABPBI matrix with well-distributed and exfoliated nanoclay, and greatly enhance the conductivity. Therefore, the $1 \mathrm{wt} \%, 3 \mathrm{wt} \%$ and $5 \mathrm{wt} \%$ membranes showed relatively low $\mathrm{E}_{\mathrm{a}}$ values

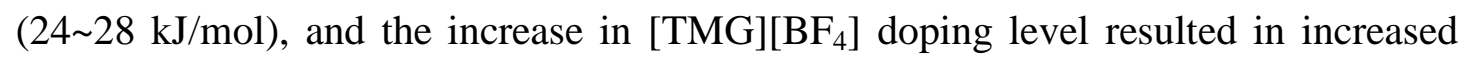


proton conductivities and reduced $\mathrm{E}_{\mathrm{a}}$ values, attributing to the shortened distance between IL molecules [23]. The high $\mathrm{E}_{\mathrm{a}}$ values of $0 \mathrm{wt} \%$ and $10 \mathrm{wt} \%$ membranes $(48.5$ and $39.3 \mathrm{~kJ} / \mathrm{mol}$ ) suggest the presence of dis-continuous ionic channels.

\section{Conclusions}

Ionic liquids doped nanoclay / sulfonated ABPBI composite membranes were prepared. Much improved mechanical properties including UTS and Young's modulus were achieved by high degree of exfoliation and well dispersion of the nanoclays in the ABPBI polymer matrix. The good dispersion of the nanoclays also increased greatly the doping levels of ionic liquids, leading to increased ionic conductivities of the composite membranes and making the sulfonated ABPBI/cloisite $\mathrm{Na}^{+} / \mathrm{ILs}$ composite membranes strong candidates for high temperature PEMFC applications.

\section{Acknowledgements}

The authors would like to express the gratitude and appreciation for Loughborough University to support the project through PhD research studentships for F. Zhang and Q.T. Liu.

\section{References}

[1] K. Joon, "Fuel cells - a 21st century power system," J. Power Sources, vol. 71, no. 1-2, pp. 12-18, 1998.

[2] H. J. Kim, S. Y. Cho, S. J. An, Y. C. Eun, J. Y. Kim, H. K. Yoon, H. J. Kweon, and K. H. Yew, "Synthesis of poly(2,5-benzimidazole)for use as a fuel-cell membrane," Macromol. Rapid Commun., vol. 25, no. 8, pp. 894-897, 2004.

[3] A.-C. Dupuis, "Proton exchange membranes for fuel cells operated at medium temperatures: Materials and experimental techniques," Prog. Mater. Sci., vol. 56, no. 3, pp. 289-327, Mar. 2011. 
[4] Q. Che, R. He, J. Yang, L. Feng, and R. F. Savinell, "Phosphoric acid doped high temperature proton exchange membranes based on sulfonated polyetheretherketone incorporated with ionic liquids," Electrochem. commun., vol. 12, no. 5, pp. 647-649, 2010.

[5] J. T. Wang and S. L. Hsu, "Enhanced high-temperature polymer electrolyte membrane for fuel cells based on polybenzimidazole and ionic liquids," Electrochim. Acta, vol. 56, no. 7, pp. 2842-2846, 2011.

[6] R. S. Malik, S. N. Tripathi, D. Gupta, and V. Choudhary, "Novel anhydrous composite membranes based on sulfonated poly (ether ketone) and aprotic ionic liquids for high temperature polymer electrolyte membranes for fuel cell applications," Int. J. Hydrogen Energy, vol. 39, no. 24, pp. 12826-12834, Aug. 2014.

[7] C.-W. Liew, S. Ramesh, and A. K. Arof, "A novel approach on ionic liquid-based poly(vinyl alcohol) proton conductive polymer electrolytes for fuel cell applications," Int. J. Hydrogen Energy, vol. 39, no. 6, pp. 2917-2928, Feb. 2014.

[8] S. Subianto, M. K. Mistry, N. R. Choudhury, N. K. Dutta, and R. Knott, "Composite polymer electrolyte containing ionic liquid and functionalized polyhedral oligomeric silsesquioxanes for anhydrous PEM applications," ACS Appl. Mater. Interfaces, vol. 1, no. 6, pp. 1173-1182, 2009.

[9] A. A. Frank Endres, Douglas MacFarlane, Electrodeposition from Ionic Liquids. Wiley-VCH, p. 30, 2008.

[10] U. Thanganathan and M. Nogami, "Investigations on effects of the incorporation of various ionic liquids on PVA based hybrid membranes for proton exchange membrane fuel cells," Int. J. Hydrogen Energy, vol. 40, no. 4, pp. 1935-1944, Jan. 2015.

[11] S.-Y. Lee, T. Yasuda, and M. Watanabe, "Fabrication of protic ionic liquid/sulfonated polyimide composite membranes for non-humidified fuel cells," J. Power Sources, vol. 195, no. 18, pp. 5909-5914, Sep. 2010.

[12] S. Liu, L. Zhou, P. Wang, F. Zhang, S. Yu, Z. Shao, and B. Yi, “Ionic-Liquid-Based Proton Conducting Membranes for Anhydrous H2/Cl2 Fuel-Cell Applications," ACS Appl. Mater. Interfaces, vol. 6, no. 5, pp. 3195-3200, 2014.

[13] A. N. Mondal, B. P. Tripathi, and V. K. Shahi, "Highly stable aprotic ionic-liquid doped anhydrous proton-conducting polymer electrolyte membrane for high-temperature applications," J. Mater. Chem., vol. 21, no. 12, p. 4117, 2011.

[14] A. Eguizábal, J.Lemus, V. Roda, M. Urbiztondo, F. Barreras, and M. P. Pina, "Nanostructured electrolyte membranes based on zeotypes, protic ionic liquids and porous PBI membranes: Preparation, characterization and MEA testing," Int. J. Hydrogen Energy, vol. 37, no. 8, pp. 7221-7234, Apr. 2012. 
[15] F. Zhang, "Hybrid nanocomposite membranes for high temperature fuel cell applications" , PhD thesis, Loughborough University. 2014.

[16] S.-W. Chuang, S. L.-C. Hsu, and C.-L. Hsu, "Synthesis and properties of fluorine-containing polybenzimidazole/montmorillonite nanocomposite membranes for direct methanol fuel cell applications," J. Power Sources, vol. 168, no. 1, pp. 172-177, 2007.

[17] H. Patel, R. Somani, H. Bajaj, and R. Jasra, "Nanoclays for polymer nanocomposites, paints, inks, greases and cosmetics formulations, drug delivery vehicle and waste water treatment," Bull. Mater. Sci., vol. 29, no. 2, pp. 133-145, 2006.

[18] N. Kakati, J. Maiti, G. Das, S. H. Lee, and Y. S. Yoon, "An approach of balancing the ionic conductivity and mechanical properties of PVA based nanocomposite membrane for DMFC by various crosslinking agents with ionic liquid," Int. J. Hydrogen Energy, vol. 40, no. 22, pp. 7114-7123, Jun. 2015.

[19] D. Plackett, A. Siu, Q. Li, C. Pan, J. O. Jensen, S. F. Nielsen, A. A. Permyakova, and N. J. Bjerrum, "High-temperature proton exchange membranes based on polybenzimidazole and clay composites for fuel cells," J. Memb. Sci., vol. 383, no. 1-2, pp. 78-87, 2011.

[20] R. W. Baker, "Membrane and Module Preparation," in Membrane Separation Systems Recent Developments and Future Directions, Noyes Data Corporation, 1991, pp. 100-146.

[21] J. A. Asensio, S. Borrós, and P. Gómez-Romero, "Sulfonated poly(2,5-benzimidazole) (SABPBI) impregnated with phosphoric acid as proton conducting membranes for polymer electrolyte fuel cells," Electrochim. Acta, vol. 49, no. 25, pp. 4461-4466, 2004.

[22] M. Doyle, S. K. Choi, and G. Proulx, "High-Temperature Proton Conducting Membranes Based on Perfluorinated Ionomer Membrane-Ionic Liquid Composites," J. Electrochem. Soc., vol. 147, no. 1 , pp. 34-37, 2000.

[23] Y.-L. Ma, J. S. Wainright, M. H. Litt, and R. F. Savinell, "Conductivity of PBI Membranes for High-Temperature Polymer Electrolyte Fuel Cells," J. Electrochem. Soc., vol. 151, no. 1, p. A8, 2004. 
International Journal of Hydrogen Energy

$20^{\text {th }}$ March 2015

Dear Sirs:

We offer the following paper for the publication in your honourable International Journal of Hydrogen Energy

\section{Paper title:}

Sulfonated Poly(2,5-benzimidazole) (ABPBI)/ MMT/ Ionic Liquids Composite

Membranes for High Temperature Proton Conducting Membranes Applications

I would declare:

The article is original;

$>$ The article has been written by the stated authors who are ALL aware of its content and approve its submission;

$>$ The article has not been published previously;

$>$ The article is not used consideration for publication elsewhere

$>$ No conflict of interest exists;

$>$ If accepted, the article will not be published elsewhere in the same form, in any language, without the written concern of the publisher.

Thank you very much for your consideration.

Best Regards,<smiles>CC(C)C=C[Al]C(C)(C)C</smiles>

Dr Xujin Bao

Senior Lecturer in Materials

Department of Materials

Loughborough University

Loughborough

Leicestershire LE11 3TU, UK

Tel: 0044 (0)1509223150

Email:x.bao@lboro.ac.uk 
Figure 6

Figure 6

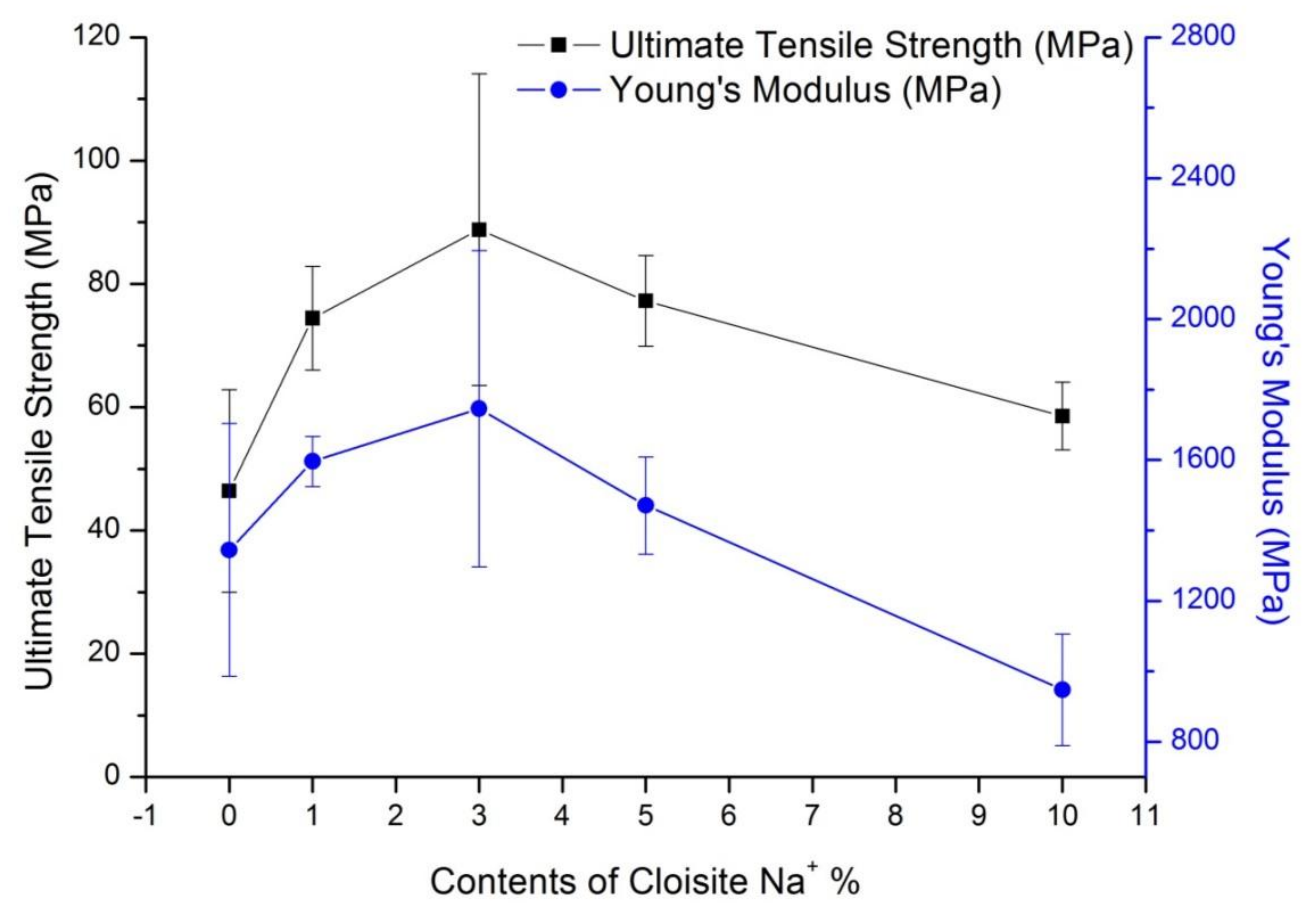


Figure 7

Figure 7

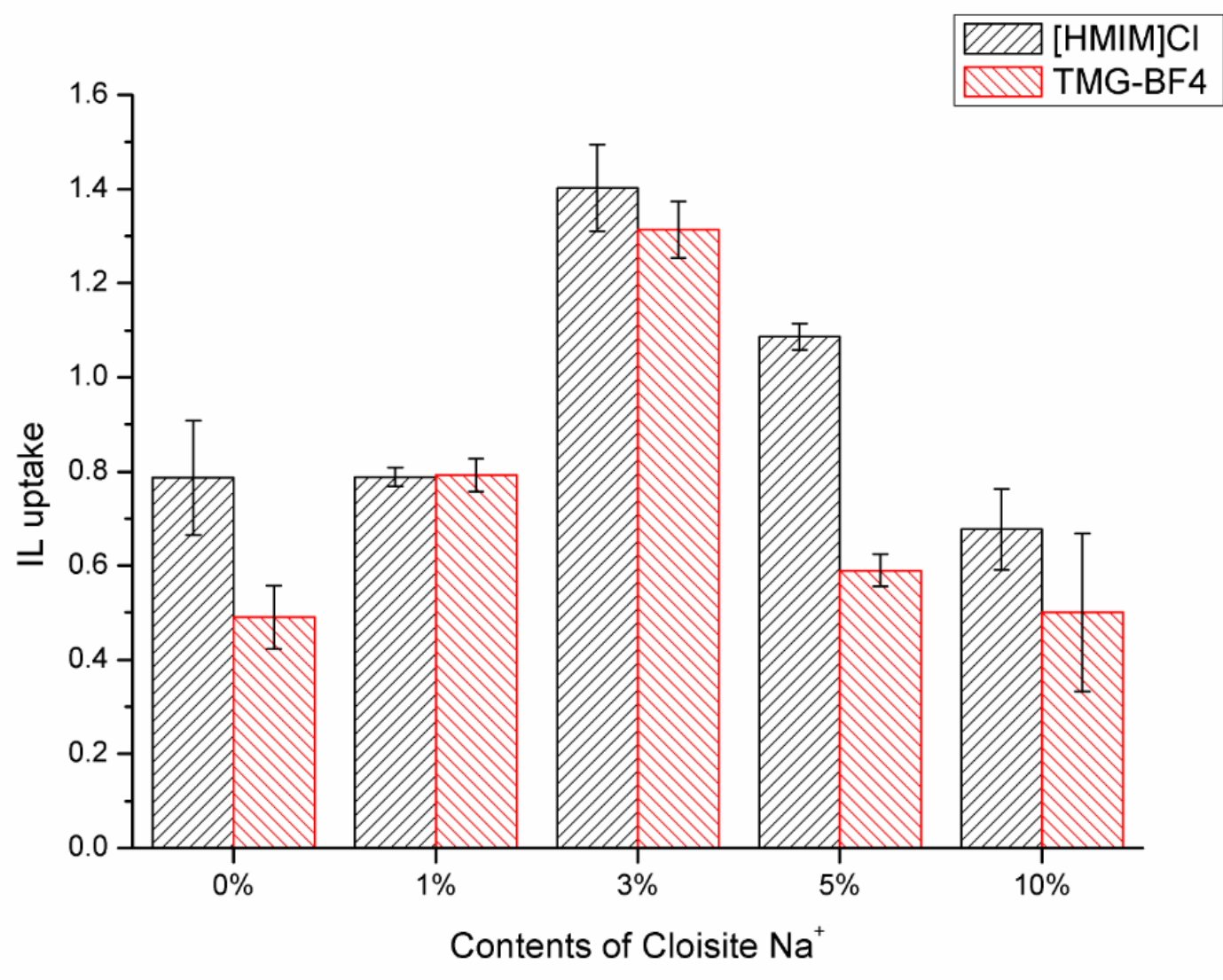


Figure 8

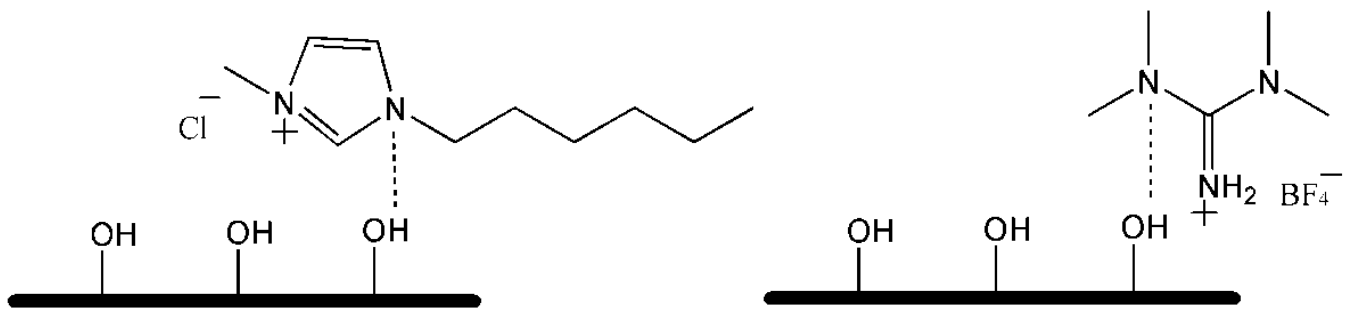


Figure 9

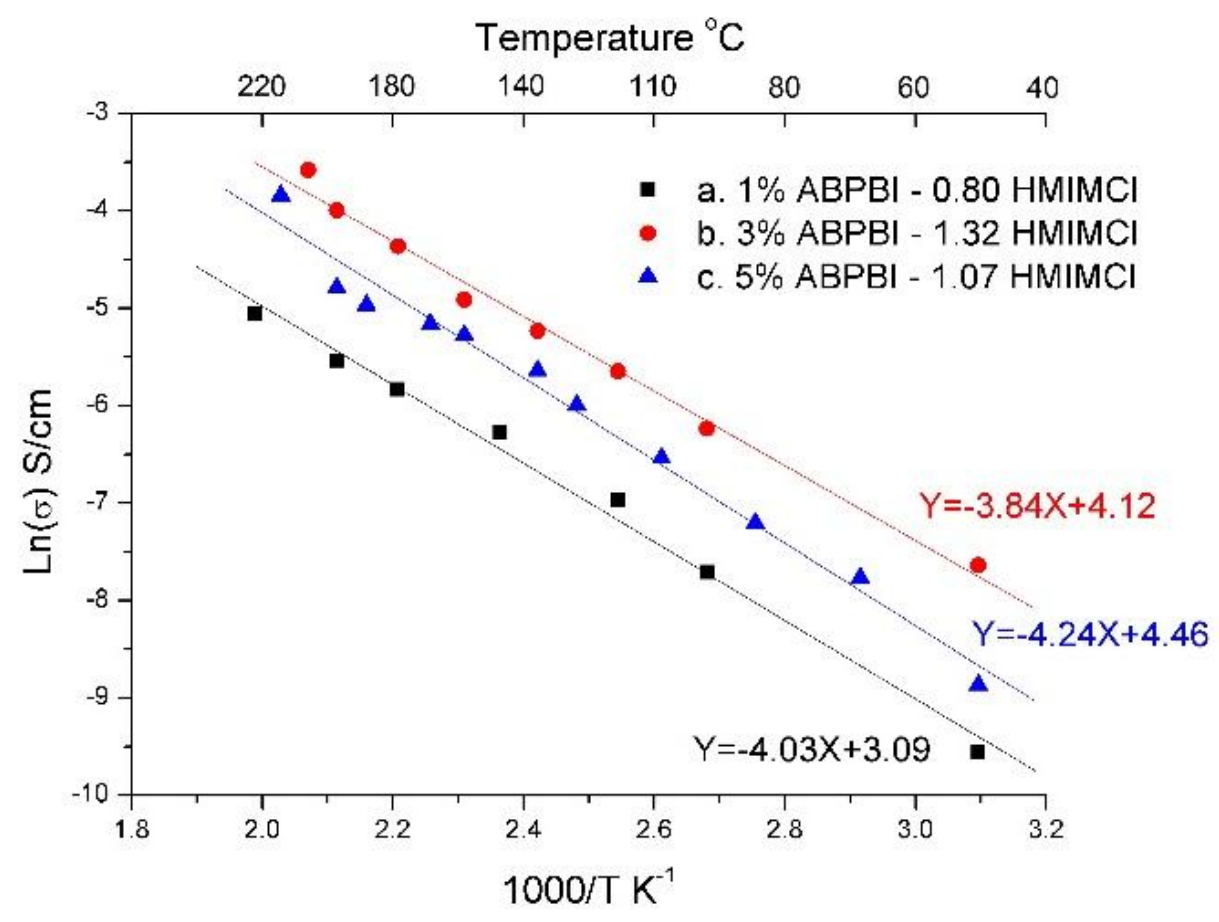

(I)

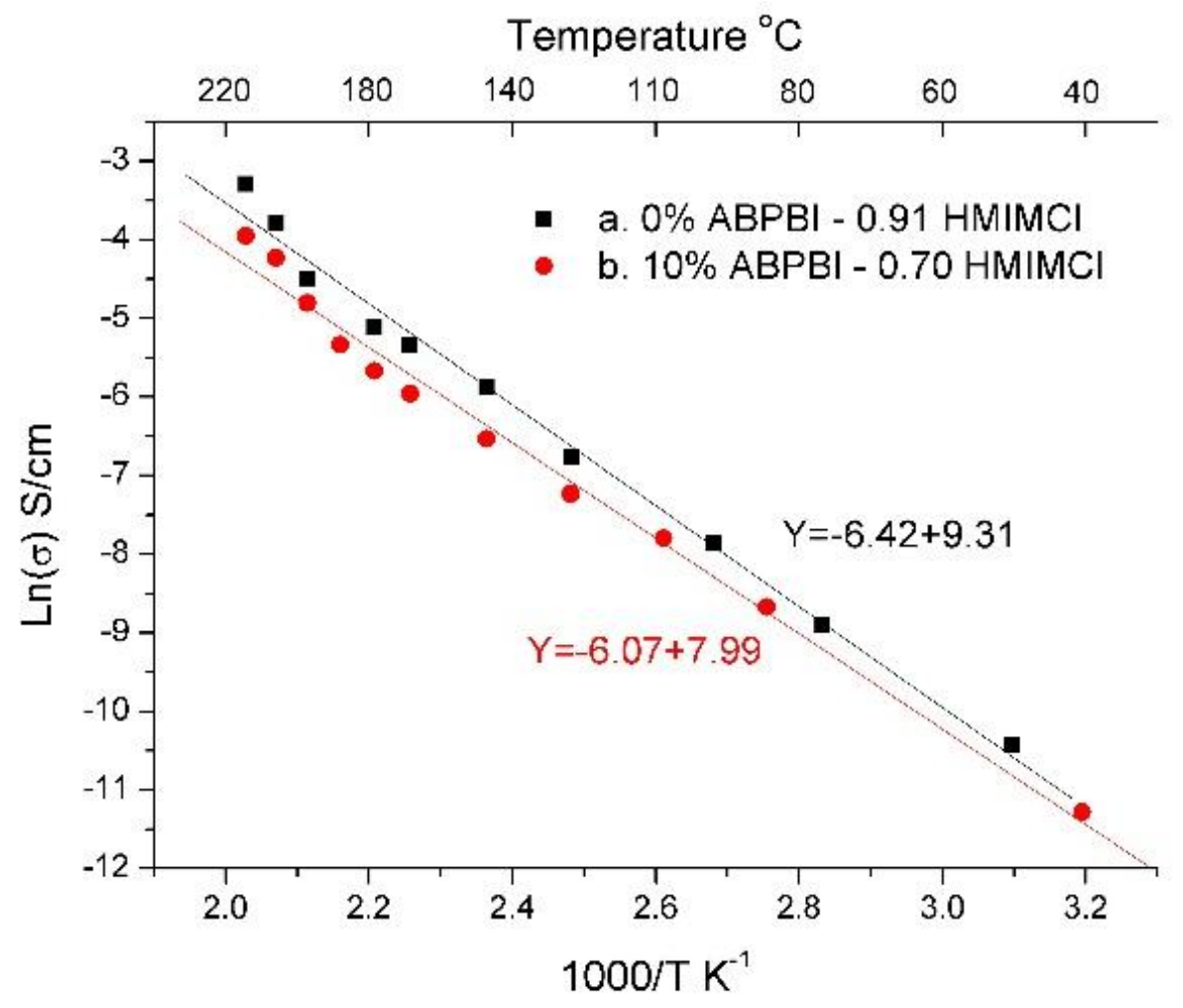

(II) 
Figure 10

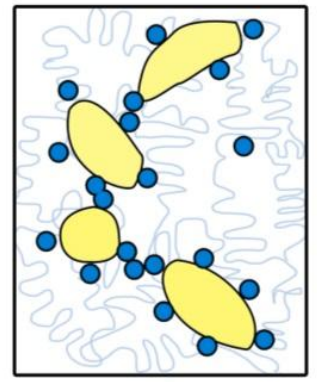

(a)

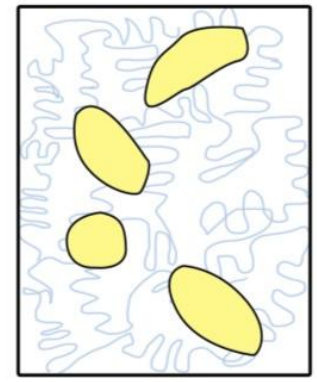

(b)

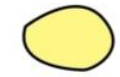

Ionic channel

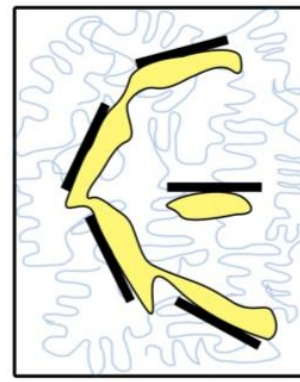

(c)

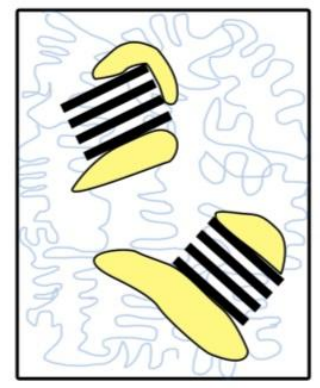

(d)
0

Water

Clay

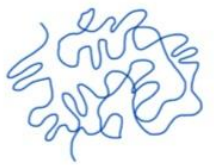

Polymer 
Figure 11

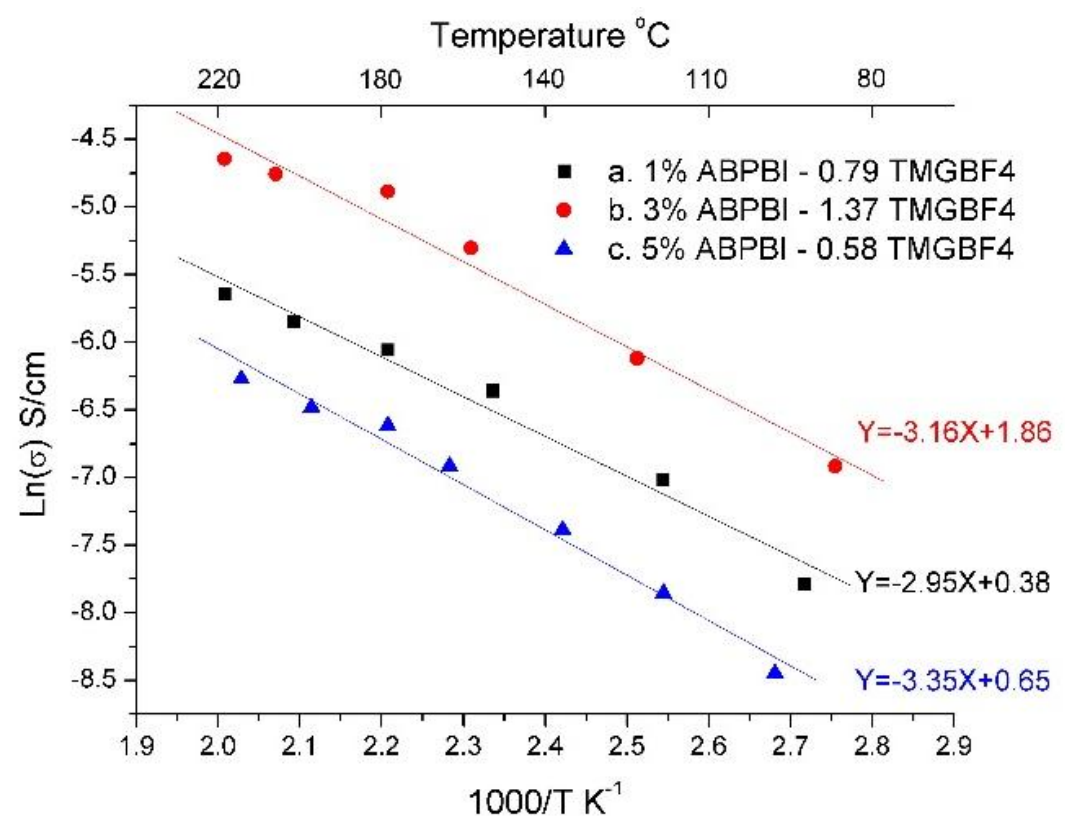

(I)

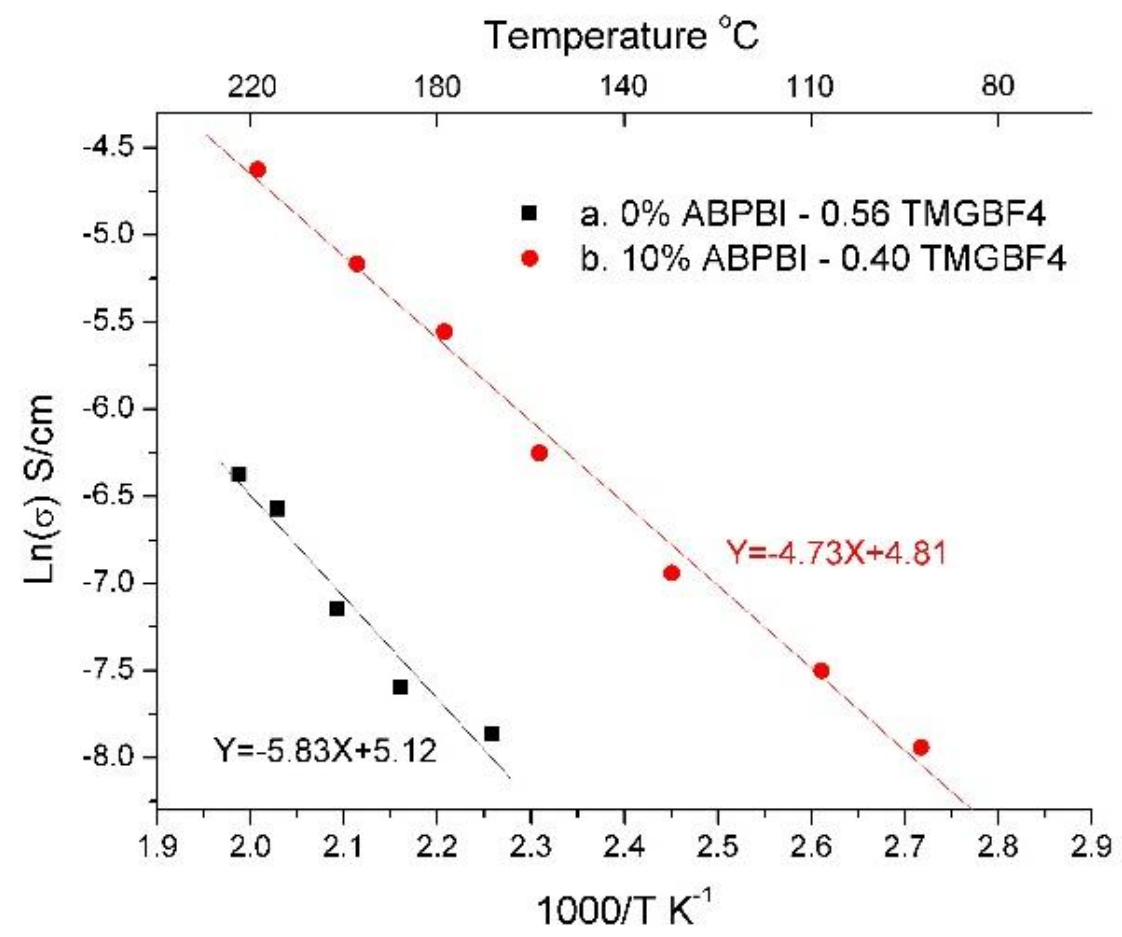

(II) 
Figure 12

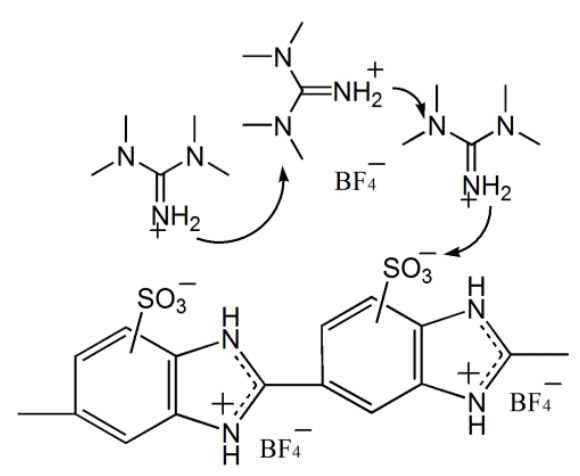

Figure 12 


\section{Highlights}

Developed new liquids (ILs) doped sulfonated ABPBI / nanoclay composite PEMs.

The composite PEMs showed a great improvement in mechanical properties.

The composite PEMs showed high proton conductivities at high temperatures $\left(>100^{\circ} \mathrm{C}\right)$. 